\title{
NOVE SPOZNAJE O OLTARNOJ SLICI SV. MARTINA IZ ŽUPNE CRKVE U VARAŽDINSKIM TOPLICAMA
}

\begin{abstract}
U prilogu su prikazani rezultati arhivskih i povijesnoumjetničkih istraživanja temeljem kojih je utvrđen povijesni slijed položaja oltarne slike sv. Martina unutar inventara u svecu posvećenoj crkvi u Varaždinskim Toplicama, a provedena konzervatorsko-restauratorska istraživanja i radovi omogućili su nova saznanja o starosti i autoru slike.
\end{abstract}

\section{UVOD}

Provođenje arhivskih, povijesno-umjetničkih i konzervatorsko-restauratorskih istraživanja, koja uglavnom prethode konzervatorsko-restauratorskim radovima, ima za cilj prikupiti sve moguće relevantne podatke koji usmjeravaju ka pravilnom pristupu konzervaciji i restauraciji te konačnoj prezentaciji umjetničkog djela. U slučaju oltarne slike sv. Martina iz župne crkve u Varaždinskim Toplicama provedena istraživanja su pripomogla u potvrđivanju starosti i autora slike, pri utvrđivanju mogućih uzroka nastalih oštećenja, ali i u rekonstrukciji povijesnog slijeda njenog položaja unutar inventara te vjerojatnih povijesnih okolnosti zbog kojih je bila uklonjena s oltara, kojemu je nedvojbeno pripadala, jer se do trenutka prije provođenja konzervatorsko-restauratorskih radova nalazila pohranjena u prostorijama župnog dvora.

Za potrebe arhivskih i povijesno-umjetničkih istraživanja na slici sv. Martina korištena je literatura o povijesti Varaždinskih Toplica i crkve objavljena od prve polovice do sredine 20. stoljeća, također su korišteni i raspoloživi arhivski podaci sa zabilješkama župnika i vizitatora te stare fotografije iz arhiva RKT župe sv. Martina u Varaždinskim Toplicama, fotografije reproducirane u stručnim i perio- 
dičnim publikacijama te fotografije iz fototeke Uprave za zaštitu kulturne baštine Ministarstva kulture.

Za razdoblje do 1882. godine bili su dostupni vrlo šturi podatci iz starije publicirane literature koji nisu bili dostatni da bi se utvrdilo točno vrijeme od otkada se slika nalazila u crkvi, gdje je izvorno bila smještena i kako je izgledao oltar za koji je bila naručena. Za razliku od toga analizom i usporedbom sačuvanih starih fotografija te dopunom podataka iz župnog arhiva i novije publicirane literature bilo je moguće pratiti povijesni slijed promjena u poziciji oltarne slike unutar crkvenog interijera od kraja 19. stoljeća do sedamdesetih godina 20. stoljeća.

U konzervatorsko-restauratorskim istraživanjima primijenjena je metoda opservacije i iskustvene procjene, izvedena su minimalna sondiranja radi utvrđivanja stratigrafije slikanih slojeva, provedene su nužne kemijske probe, a kombinacijom svih njih definirane su materijalne specifičnosti slike i formalno-stilske karakteristike njene izvedbe.

Prikupljena arhivske građa i podatci koji su iz nje iščitani dali su naslutiti da je povijest slike mnogo složenija, nego što se u samom početku pretpostavljalo, budući da je u više navrata mijenjala položaj na oltaru. Pored toga, tijekom konzervatorsko-restauratorskih radova nakon uklanjanja ukrasnog okvira otkrivana je izvorno sačuvana signatura autora s godinom nastanka što je bilo od presudnog značenja u korekciji ranije datacije slike.

\section{DOSADAŠNJA SAZNANJA O POVIJESTI CRKVE I INVENTARA}

Čabrijan citira Tkalčića i njegov podatak da je već u 13. stoljeću, na mjestu starije crkve sagrađena gotička crkva koja se spominjala 1334. godine u popisu župa Zagrebačke biskupije. Ta kasnogotička faza ostala crkve ostala je vidljiva samo u ukrasnim potpornjacima s vanjske strane apside svetišta i djelomično u donjoj zoni zvonika. Lađu je u ranijoj fazi prekrivao oslikani drveni tabulat. Tijekom 18. stoljeća uslijedila je njena barokizacija te je 1762. godine tabulat zamijenjen baroknim svodom. Iste godine crkva je dozidana i podignut je kor, a 1765. nabavljene su nove orgulje A. Römera iz Graza. Nešto kasnije na južnoj strani crkve dograđena je kapela žalosne Majke Božje. ${ }^{1}$

Božena Filipan navodi iz starije literature podatke kako je Kaptol, koji je polagao pravo crkvenog posjeda u Varaždinskim Toplicama, darovao topličkoj župnoj crkvi dva „nova“ barokna, mramorna oltara sv. Katarine i sv. Barbare ${ }^{2}$ koji

\footnotetext{
Josip ČABRIJAN, „Varaždinske Toplice u srednjem vijeku“, Vijesti muzealaca $i$ konzervatora Hrvatske, 15/5, Zagreb, 1966., 19.

2 Oltari su djelo poznatog talijanskog kipara Francesca Robbe koje je 1738. godine izradio za zagrebačku katedralu, U: Enciklopedija likovnih umjetnosti, sv. 4, Zagreb, 1966., 103.
} 
su prilikom obnove zagrebačke katedrale, nakon potresa 1881. godine, bili iz nje uklonjeni. ${ }^{3} \mathrm{O}$ tome da je pobočni oltar sv. Katarine iz zagrebačke katedrale 1884. godine postao glavni oltar župne crkve sv. Martina u Varaždinskim Toplicama, dok je oltar sv. Barbare postavljen uz sjeverni zid lađe, piše već i Szabo. ${ }^{4}$

Crkva je do danas sačuvana kao jednobrodna građevina s poligonalnim svetištem i korom iznad glavnog ulaza na baroknom pročelju. S južne strane lađe, u produžetku drugoj svodnog polja, tlocrt je raščlanjen pravokutnom kapelom s pokrajnjim ulazom u crkvu. Nešto niže uz južni zid izduženog svetišta smještena je sakristija s kružnim stubištem koje vodi na oratorij. Uz sjeverni zid lađe prigrađen je četvrtasti korpus zvonika s lukovicom. Na crkvu se sa sjeverne strane naslanja trokrilni, jednokatni barokni dvor s arkadnim trijemom u prizemlju te s crkvom formira zatvoreni kvadrat unutarnjeg dvorišta. A da je dvorac nastao u 17. stoljeću preuređenjem dijela starog Topličkog kastela iz 14. stoljeća bilježi u konzervatorskoj dokumentaciji i kasnije objavljuje Ivy Lentić Kugli. ${ }^{5}$

U njegovom prizemnom dijelu danas je smješten Zavičajni muzej Varaždinske Toplice.

\section{OSNOVNI PODATCI O OLTARNOJ SLICI SV. MARTINA}

Slika sv. Martina iz župnog dvora u Varaždinskim Toplicama nalazila se do 70tih godina 20. st. na glavnom oltaru. Evidentirana je kao rad nepoznatog majstora i datirana u 18. stoljeće. ${ }^{6}$ Izrađena je tehnikom uljanih boja na lanenom nosiocu, a dimenzije su joj 186 x 107 cm s radijusom završnog luka od 53,5 cm. Napeta je na drveni podokvir te smještena unutar uskog drvenog, jednostavno profiliranog i pozlaćenog ukrasnog okvira.

Oltar sv. Katarine prilikom premještanja u topličku crkvu nije prenesen u originalu sa svim pripadajućim skulpturama. Na njemu se danas nalaze skulpture sv. Matije i sv. Bartolomeja s oltara sv. Barbare, a skulptura sv. Adrije apostola s atike postavljena je na oltar u župnoj crkvi u Sisku, dok anđeli na volutama uopće nisu Robbin rad. U: Vera HORVAT PINTARIĆ, Francesco Robba, Zagreb, 1961, 81.

3 Oltari su u katedrali stajali jedan nasuprot drugome kod prvog stupa svetišta, uklonjeni su 1882. godine prilikom obnove katedrale koju je vodio Herman Bolle. Ti oltari su poznati kao „,zagrebački oltari“, ali su u Toplice došli bez dva mramorna kipa koji su završili na drugom kaptolskom posjedu u Sisku. U: Božena FILIPAN, „Barokna baština Varaždinskih toplica s osvrtom na zaštitu i revitalizaciju“, Zavod za znanstveni rad HAZU Varaždin, Radovi Zavoda za znanstveni rad HAZU Varaždin, 8-9, Zagreb-Varaždin, 1996., 51.

4 Đuro SZABO, Kroz Hrvatsko zagorje, Zagreb, 1939., 196.

5 Ivy LENTIĆ KUGLI, „Arhitektura u povijesnoj urbanoj cjelini Varaždinskih Toplica“, Arhitektura 154/1975., Zagreb, 1975., 57.

6 Prema Rješenju za upis u Registar kulturnih dobara RH pod registarskim brojem Z-1496. Klasa: UP/I-612-08/03-01-06/535 Ur. broj: 532-10-1/8-04-2 od 18. 3. 2004. 
Venija Bobnjarić-Vučković: Nove spoznaje o oltarnoj slici sv. Martina iz župne crkve u Varaždinskim Toplicama Radovi Zavoda za znanstveni rad HAZU Varaždin; br. 29, 2018., str. 53-84

\section{IKONOGRAFSKA I FORMALNA ANALIZA}

Sv. Martin biskup ${ }^{7}$ bio je vrlo štovani svetac na području sjeverozapadne Hrvatske. Još i danas je titular mnogih crkava i kapela pa se njegov lik može pronaći na mnogim slikama ili skulpturama koji rese oltare. Rođen je u Panoniji u 4. stoljeću, a na očev zahtjev gradio je vojničku karijeru u Francuskoj. Međutim, prevagnula je njegova vjera u Boga pa se posvetio asketskom redovničkom životu, čak je i protiv svoje volje imenovan biskupom u Toursu. Na tu je dužnost nevoljko pristao. Guska koja je u potrazi za imenovanim biskupom, prema legendi, svojim gakanjem otkrila njegovo samotničko skrovištečesto se postavlja uz lik sv. Martina kao njegov atribut u skulpturalnim prikazima, dok se na slikama češće prikazuje u sceni darivanja plašta siromahu.

U slikarskom mediju često se koristila mogućnost da se slika kompozicijski strukturira sa dvije paralelne scene, od kojih je jedna glavna i dominira platnom, a druga sporedna i prikazana u manjem segmentu platna, što je karakteristika slike koja je predmet ovog istraživanja.

Kompozicijom slike dominira (Slika 1.) lik sv. Martina u punoj figuri na oblacima. Prikazan je u liku starca sijede brade i brkova koji je pokleknuo desnom nogom na oblak. Biskupski štap, pastoral, drži ispred sebe u laktu savijenoj desnoj ruci dok mu je lijeva ispružena uz lijevi bok. Odjeven je u biskupski ornat, albu i roketa, preko kojih visi stola, te je ogrnut plaštem koji pada u naborima na obje strane. Na sijedu, kratko podšišanu kosu nataknuta mu je biskupska mitra. U pozadini dominantnog lika biskupa sv. Martina dočarano je nebesko plavetnilo prošarano sivo-bijelim nakupinama oblaka, a među njima su raspoređene skupine glavica kerubina i anđela adoranata. U donjem, manjem segmentu slike prikazana je scena iz života sv. Martina. On se kao mladi vojnik na konju smilovao se siromahu i darovao mu dio svojega plašta kojeg sječe mačem. Scena je smještena u skromno naslikanom pejzažu kojim dominira veliko ogoljelo stablo i pročelje crkve.

U samoj figuri sveca i njenoj posturi uočava se slikarska nespretnost i netočnost kako u samom pozicioniranju pojedini dijelova tijela (posebno njegovih udova) u odnosu na njegov torzo, tako i u dojmu cjeline što ostavlja dojam ukočenosti i statičnosti. Glava s licem sveca naslikana je s vidljivom pažnjom i preciznošću pri izradi i obradi detalja, dok su draperije njegove odjeće izvedene $u$ jednostavnim, stiliziranim i krutim, linearnim naborima. Likovi anđela adoranata, posebno njihova tjelešca, također su izvedeni anatomski netočno i nespretno, u neprirodnim i statičnim pozama, a njihova lica kao i lica kerubinskih glavica

\footnotetext{
U: Leksikon ikonografije, liturgike i simbolike zapadnog kršćanstva, Zagreb, 1990., 397.
} 
ostavljaju dojam ukočenog izraza. Prizorom prevladava ujednačeno raspršena blaga svjetlost koja dolazi iz prednjeg plana, pa su svi segmenti prizora izvedeni lazurno i tonski ujednačenim koloritom i blagom modelacijom oblika koja je postignuta nježnim prijelazima s prednjih, osvjetljenijih ka bočnim, zasjenjenijim dijelova.

Za razliku od gornjeg prikaza koji je minuciozan u detaljima, naglašeno linearan i plošno oblikovan, donja narativna scena izvedena je sasvim drugačijom slikarskom metodom. Lik sv. Martina na konju i prosjaka pored ogoljelog drveta u prednjem, lijevom planu donjeg prizora izvedeni su u dinamičnijim posturama koje se doimaju anatomski manje nespretnima. U modeliranju volumena figuralne kompozicije korišteni su jači kontrasti osvjetljenijih i zasjenjenijih dijelova primjenom šireg spektra kolorita i isprekidanih, lomljenih poteza kista. U definiranju prostora, u koji su figure smještene, korišteni su krajnje reducirani pejzažni elementi prikazani s manje detalja u kratkim potezima i krajnje reduciranom koloritu smeđih i plavo-zelenih tonova. Pejzaž se gradi u dubinu kroz nekoliko slojeva koji se nižu jedan za drugim od lijeva na desno da bi se oni krajnji izgubili u izmaglici. Scena djeluje vrlo dinamično i ekspresivno.

\section{ARHIVSKA I POVIJESNO-UMJETNIČKA ISTRAŽIVANJA}

Samom činjenicom da je slika sv. Martina recentno zatečena u župnom dvoru te da su već u početnoj fazi prikupljanja dokumentacije za konzervatorsko-restauratorska istraživanja i radove uočene mnoge promjene i preinake na inventaru župne crkve sv. Martina tijekom 19. i 20. stoljeća istraživanja su proširena te dijelom usmjerena i na utvrđivanje konteksta promjena koje su se tijekom povijesti crkve desile na inventaru i posebice na glavnom oltaru sv. Martina.

Čabrijan navodi podatak da je crkva tijekom druge polovice 18. stoljeća, nakon temeljite barokizacije i dogradnje kapele žalosne Majke Božje imala ukupno sedam oltara. ${ }^{8}$ U više navrata su objavljeni podaci o dva barokna mramorna oltara sv. Katarine i sv. Barbare koji su između 1882. i 1884. godine dopremljena iz zagrebačke katedrale u crkvu sv. Martina u Varaždinske Toplice. ${ }^{9}$ Čabrijan i Filipan spominju podatak da je prilikom preseljenja i postavljanja u topličku crkvu oltar sv. Katarine postavljen u svetište preuzimajući ulogu glavnog oltara, zamijenivši dotadašnji stariji. Prilikom postavljanja kamenog oltara sv. Katarine, reljef s prikazom mučeništva sv. Katarine dislociran je sa svoje izvorne pozicije

Josip ČABRIJAN, n. d. 19. Kako su izgledali ti oltari, a posebice glavni oltar, nije navedeno, baš kao ni podatak je li dio toga oltara bila do danas sačuvana slika sv. Martina.

9 Oltari su premješteni iz zagrebačke katedrale nakon njene rekonstrukcije zbog oštećenja nastalih prilikom velikog potresa 1881. godine. Josip ČABRIJAN, n. d. 20. 
na oltaru te je uzidan u sjeverni zid lađe, neposredno do propovjedaonice. $\mathrm{Na}$ mjesto kamenog reljefa postavljena je slika sv. Martina, patrona crkve.

Pomnijim promatranjem vidljivih detalja na fotografiji koju je objavio Gjuro Szabo 1915. godine (Slika 2) naziru se obrisi lijevog ruba reljefa sv. Katarine na sjevernom zidu lađe što potvrđuje Čabrijanov i Filipankin podatak da je reljef zaista bio uklonjen s kamenog oltara preseljenjem u topličku crkvu i bio postavljen na sjeverni zid lađe te da je na tom novom glavnom oltaru umjesto reljefa postavljena slika patrona crkve sv. Martina biskupa koja i te 1915. godine još uvijek bila sastavni dio glavnog oltara.

Na fotografiji G. Griesbacha iz tridesetih godina 20. stoljeća (Slika 3), koja se čuva u Upravi za zaštitu kulturne baštine u Zagrebu, dokumentirano je prethodno opisano stanje glavnog oltara sa slikom sv. Martina kao oltarnom palom. $\mathrm{Na}$ istoj fotografiji se nazire i kip nepoznate svetice (vjerojatno Majke Božje) u niši atike oltara koja je, prema ranije objavljenim podacima, popunila prazninu gdje je stajala kamena skulptura svetice izvorno izvedene za oltar sv. Katarine. ${ }^{10}$ Oba predmeta, glavna oltarna pala i kip u atici, obrubljeni su bijelim vjenčićima koji, kako je kasnije utvrđeno, predstavljaju žarulje kojima su bili osvijetljeni. Ova pretpostavku potvrđuje podatak iz spomenice o uvođenju elektrike u crkvu 1929. godine, a što se podudara s razdobljem neposredno prije nastanka ove fotografije. Na istoj fotografiji je vidljivo svetohranište, tabernakul, svijetle boje s tamnijim ukrasnim elementima pozicionirano $u$ sredini menze ispred predele oltara. Na svetohraništu s fotografije se vide naznake središnje niše prekrivene zavjesicom i bočno pozicionirana dva para stupića s kapitelima. Na njih naliježe ravni, profilirani vijenac koji se iznad središnje niše izvija u luk s križem povrh svega. ${ }^{11}$ Bočno s obje strane svetohraništa dva su pravokutna, ostakljena okvira svjetlijeg tona obojenja. Za pretpostaviti je da ostakljeni okviri predstavljaju dva moćnika, relikvijara, Mater Christi i A spinis coronatus iz druge polovice 18. st. koji se danas, također, čuvaju u župnom dvoru. ${ }^{12}$

10 Obje kamene skulpture svetica na konzolama, koje su izvorno namijenjene za oltare sv. Katarine i sv. Barbare, su prilikom preseljenja oba oltara iz katedrale bile uklonjene te su završile na drugom kaptolskom imanju u Sisku. Božena FILIPAN, n. d. 51. i Josip ČABRIJAN, n. d. 20.

11 U veljači 2012. godine, neposredno prije preuzimanja slike, u crkvi je evidentirano drveno, bijelo polikromirano i pozlaćeno svetohranište s dva para pilastara koja flankiraju vratašca ukrašena pozlaćenim reljefima. Svetohranište se nalazilo u niši sa stražnje strane glavnog oltara, dok je na oltaru bio noviji. (Slika 4).

12 Na moćnicima su provedeni konzervatorsko-restauratorski radovi od 2012. do 2014. godine. Prilikom istražnih radova sondiranjem na kućištima je utvrđeno da sloj preslika bijelom bojom i imitacijom pozlate prekriva izvorni slikani sloj olovnom bijelom s pozlaćenim elementima (rozetama i dijelovima profilacija okvira i postolja). U: Arhiva HRZ RCL-a Dos. br. RCL 56.3. 
Može se pretpostaviti da su ti drveni, bijelo polikromirani te pozlaćeni elementi crkvenog inventara nastali u razdoblju neposredno nakon barokne obnove crkve krajem 18. ili početkom 19. stoljeća ${ }^{13}$ što bi moglo upućivati na zaključak da je i „stari“ glavni oltar nastao u istoj zlatno-bijeloj maniri tipičnoj za kasnobarokno-klasicističku stilsku fazu.

Slijedi fotografija iz spomenice RKT župe sv. Martina iz 1954. godine (Slika 5) koja potvrđuje da se oltarna slika sv. Martina pedesetih godina 20. stoljeća još uvijek nalazila na retablu oltara, ali bez vjenčića od žarulje, kao i kip Majke Božje u niši atike. No, više se ne vide moćnici, kao ni starije svetohranište koje je zamijenjeno novijim, kamenim jednostavnog pravokutnog korpusa s metalnim, reljefno ukrašenim vratašcima. ${ }^{14}$

Nadalje, u spomenici župe je zabilježena još jedna promjena u crkvi i na oltaru jer je nakon pedesetih godina 20. stoljeća reljef sv. Katarine ponovno vraćen na svoje izvorno mjesto u retabl glavnog oltara, dok je slika sv. Martina premještena na atiku oltara s koje je uklonjen kip Majke Božje. ${ }^{15}$ Ovaj podatak potvrđuje fotografija s pogledom na svetište crkve koja se nalazi na razglednici Varaždinskih Toplica iz 1979. godine (Slika 6), a čuva se spomenici župe.

Budući da nakon tog vremena nema zabilježenih podataka o premještanju slike, može se samo pretpostaviti da je tijekom osamdesetih godina 20. stoljeća slika uklonjena s atike glavnog oltara i pohranjena u župni dvor vjerojatno zbog velikih oštećenja koja se daju naslutiti na fotografiji sa spomenute razglednice. Na mjesto iste u nišu atike postavlja se kip sv. Martina (kameni ili drveni u monokromnoj, bijeloj boji). Isti raspored slikarskih i kiparskih elemenata na oltaru zatečen je i početkom 2012. godine. Tom prilikom uočena je $\mathrm{i}$ jedna novina $\mathrm{u}$ odnosu na stanje iz 70tih godina, a odnosila se na promjenu kamenog svetohranište iz 50tih novijim, također, kamenim koje kompozicijski i kromatski podsjeća na ono najstarije dokumentirano na fotografiji iz 1930tih godina. Ove promjene zabilježene su na fotografijama nastalima tijekom pregleda stanja oltara u crkvi kao i oltarne slike sv. Martina u župnom dvoru od

13 Kako je poznato da se olovno bijela boja na veliko koristila u 18. st., a da se tijekom druge pol. 19. st. sve više počela pratiti kakvoća njene primjene, pogotovo u umjetničkim djelatnostima, te je $u$ prvoj polovici 20. st. bila zabranjena njena primjena u restauratorskoj djelatnosti (HERING, Weisse Pigmente, Nürnberg, 2000, 82), sve upućuje na zaključak da su moćnici mogli nastati tijekom druge polovice 18. st. ili u prvoj polovici 19. st. s barokno-klasicističkim stilskim značajkama, a da su naknadno u drugoj polovici 19. st. ili početkom 20. st. bili preslikani u istom tonskom odnosu. Podatak o zamjeni svetohraništa novim, kamenim zabilježen je i u spomenici župe.

15 Podatak o vraćanju reljefa sv. Katarine na glavni oltar zabilježen je u spomenici župe, a dokumentiran je i na razglednici crkve iz 1979. godine na kojoj je još uvijek kameno svetohranište iz pedesetih godina 20 . stoljeća. 
Venija Bobnjarić-Vučković: Nove spoznaje o oltarnoj slici sv. Martina iz župne crkve u Varaždinskim Toplicama Radovi Zavoda za znanstveni rad HAZU Varaždin; br. 29, 2018., str. 53-84

strane restauratora Restauratorskog centra Hrvatskog restauratorskog zavoda u Ludbregu (Slika 7. i 8.). ${ }^{16}$

Nakon preuzimanja slike iste 2012. godine radi konzervatorsko-restauratorskih radova i početnih radova na uklanjanju ukrasnog okvira, u donjem desnom uglu jasno je postala vidljiva signatura autora i godina nastanka djela "Joh. Beyer, 1852." koja upućuje na štajerskog slikara i restauratora Johanna Beyera. ${ }^{17}$ (Slika 9.)

Johann Beyer je svoje područje djelovanja proširio od Austrije preko Slovenije do sjeverozapadne Hrvatske gdje je djelovao u periodu između 1846. i 1860. godine izrađujući uglavnom oltarne slike za crkve ${ }^{18}$. Tako se već 1847 . godine bilježi njegov boravak u Zagrebu gdje je dovršavao dvije oltarne slike za crkvu u Pregradi. ${ }^{19}$ U Hrvatskom biografskom leksikonu se spominje i podatak da je isti autor izradio sliku za crkvu u selu Svibovec pored Varaždinskih Toplica, ali nije navedena godina nastanka. No, sasvim je sigurno da je slika u Svibovcu nastala u vrijeme Beyerovog boravka u Hrvatskoj, a kako je u to vrijeme crkva u Varaždinskim Toplicama imala još stare oltare vrlo je vjerojatno da je tijekom boravka u Svibovcu od autora naručena i slika za postojeći glavni, barokni oltar u Varaždinskim Toplicama.

\section{KONZERVATORSKO-RESTAURATORSKA ISTRAŽIVANJA}

U okviru konzervatorsko-restauratorskih istraživanja primjenom metode opservacije dobivene su sljedeće informacije o slici:

a) za platneni nosilac upotrijebljeno je vrlo tanka i fino tkana, vjerojatno, lanena tkanina u platno-vezu, ${ }^{20}$ čija gustoća tkanja iznosi 18 × 20 niti po cm²;

16 Konzervatorsko-restauratorskim radovima nisu prethodila mjerenja temperature i relativne vlage u prostoriji 1. kata župnog dvora, gdje se slika čuvala do preuzimanja, jer su, prema iskustvenoj procjeni restauratora tijekom radova, zatečena oštećenja nastala kao rezultat dugotrajne izloženosti nepovoljnim mikroklimatskim uvjetima u samoj crkvi.

17 Johan Beyer (1801.-1876.) nakon povratka sa školovanja za slikara u Beču i Rimu od 1832. godine posvećuje se religioznom slikarstvu, radeći na mnogim oltarnim slikama za razne crkve u Štajerskoj, Koruškoj, Kranjskoj, Hrvatskoj i Sloveniji. U: Hrvatski biografski leksikon, Zagreb, 1983., 734-735.

18 U Hrvatskom biografskom leksikonu je navedeno da je izradio oltarne slike za crkve u Cerju 1847., Pregradi 1847., Ivanić Gradu 1848.-1850., Dugom Selu 1852., Voloderu 1855., Varaždinu 1857. U: Hrvatski biografski leksikon, Zagreb, 1983., 734-735.

19 Agramer Zeitung (Zagreb) od 30. 11. 1847., br. 96, 430.

20 Platno vez je jedan od tri temeljna veza tj. predstavlja jednu od tri osnovne kombinacije preplitanja osnove i potke, koji ima jednu osnovinu i jednu potkinu veznu točku u jedinici veza, a označava se kao P 1/1 .(Stana KOVAČEVIĆ, Ručno tkanje, Zagreb, 2003., 84-85.) 
Venija Bobnjarić-Vučković: Nove spoznaje o oltarnoj slici sv. Martina iz župne crkve u Varaždinskim Toplicama Radovi Zavoda za znanstveni rad HAZU Varaždin; br. 29, 2018., str. 53-84

b) platno za sliku sastavljeno je od jedne širine tkanog platna sa sačuvanim živim rubom s lijeve i desne bočne strane slike i bez prisutnih šavova sa stražnje strane;

c) podokvir je bio izrađen od drva četinjače (jela / smreka), profila letve $18 \mathrm{x}$ $70 \mathrm{~mm}$; ima oblik izduženog pravokutnika s lučnim završetkom širine luka 109 $\mathrm{cm}$ i $\mathrm{R}=54,5 \mathrm{~cm}$. Sastavljen je od šest dijelova spojenih na utor / pero, a u završnom lučnom dijelu s tri spoja na utor / pero dodatno lijepljena tutkalom. Podokvir ima križno ojačanje od dvije letve profila 18 x $48 \mathrm{~mm}$ spojene međusobno križnim spojem $\mathrm{s}$ dva utora od $1 / 2$ debljine. Krajevi križnog ojačanja spojeni su $\mathrm{s}$ okvirom na dužinski spoj rupa / čep. U uglovima na dnu okvira nalaze se po dvije kajle (drvo oraha), a na uglovima pri spojevima letvi križnog ojačanja s bočnim stranicama okvira i na tjemenu luka nalazi se po jedna kajla;

d) platno je bilo učvršćeno na drveni podokvir čavlićima;

e) ukrasni okvir u koji je slika bila umetnuta je recentni, uski drveni jednostavno profilirani i pozlaćeni okvir koji je svojim skromnim profilom bio neprimjeren dimenzijama slike.

f) nakon uklanjanja ukrasnog okvira uočeni su tragovi korekcija dimenzija slike skraćivanjem na njezinu donjem rubu u širini od oko $4 \mathrm{~cm}$, kao i na gornjem lučnom dijelu u širini od oko $2 \mathrm{~cm}$. Na tim mjestima je nakon uklanjanja ukrasnog okvira i podokvira bio uočljiv pregib preko slikanog sloja, tragovi rupa od čavala i rub do kojega je nanesen potamnjeli lak;

Izvedena minimalna mehanička i kemijska sondiranja s lica slike imala su za cilj odrediti stratigrafiju slikanih slojeva kako bi se utvrdilo da li je prezentiran izvorni slikani sloj ili su na njemu bile izvedene naknadne intervencije preslikavanjem. Kemijske probe bile su usmjerene na pronalaženje metode uklanjanja sloja prljavštine, laka i eventualnih preslika.

Ova istraživanja ukazala su na sljedeće karakteristike pri nastajanju slike:

a) slika ima četiri sloja: platneni nosilac, sloja preparacije, izvorno sačuvani slikani sloja te završni sloja zaštitnog laka;

b) na platneni nosilac nanesen je vrlo tanak sloj kredno-tutkalne preparacije kroz koju je ostala vidljiva tkana struktura platnenog nosioca;

c) slikani sloj bio je nanesen u vrlo tankim, lazurnim slojevima uljanih boja s vidljivom teksturom platnenog nosioca;

d) kao završni zaštitni sloj bio je nanesen sloj laka koji je s vremenom poprimio tamni ton. Može se zaključiti da je korišten damar lak, budući da on ima tendenciju tamnjenja. ${ }^{21}$

21 Damar lak se počeo koristi kao zaštitni sloj od druge polovice 19. st. U: R. FELLER, „First description of dammar picture varnish translated“, Bulletin of the American Group. International Institute 
Venija Bobnjarić-Vučković: Nove spoznaje o oltarnoj slici sv. Martina iz župne crkve u Varaždinskim Toplicama Radovi Zavoda za znanstveni rad HAZU Varaždin; br. 29, 2018., str. 53-84

Detaljnije laboratorijske analize $\mathrm{u}$ svrhu identifikacije vrste tekstilnih niti platnenog nosioca, korištenih pigmenata i veziva u slikanom sloju, kao i mikroskopske stratigrafije slojeva nisu rađene zbog nedostatka vremena i ograničenih materijalnih sredstava.

\section{ZATEČENO STANJE SLIKE}

Promatranjem površine slike (Slika 10. i 11.), uočena su višestruka oštećenja nastala djelovanjem različitih faktora kao što su povijesne okolnosti čestog premještanja, nepravilno izlaganje i čuvanje, starenje materijala kao i djelovanje vanjskih utjecaja: štetnih zraka sunčevog spektra svjetlosti, oscilacija temperature i relativne vlage, prašine u zraku, mikroorganizama i nametnika te raznih prljavština životinjskog porijekla.

Uočena oštećenja prisutna su u svim slojevima od platnenog nosioca, slikanog sloja do podokvira:

a/ drvo podokvira bilo je puno čvorova koji su uzrokovali deformaciju letava, bila su vidljiva oštećenja djelovanjem drvnih nametnika, kutni spojevi su bili oslabljeni. Sve to je utjecalo na oslabljivanje već ionako relativno slabe konstrukcije od tankih drvenih letvica s poprečnim križem postavljenim na pola visine, a ukupna nestabilnost utjecala je na opuštanje platna i stvaranje nabora po njegovim rubovima (Slika 12-14). Konstrukcija podokvira bila je preslaba za format slike, koji je trebala nositi.

b/ Platneni nosilac slike od vrlo je fino i tanke tkanine, koja je zbog vremenskog starenja i istrošenosti postala još tanja i poroznija, što je naročito bilo uočljivo na mjestima gdje je slikani sloj otpao. Zatečeno je i nekoliko manjih poderotina i rupa, od kojih je jedna bila nestručno sanirana lijepljenjem novije, grublje tkanine u platno vezu i tako učvršćena na naličju slike.

c/ Slikani sloj bio je izvorno sačuvan, bez naknadno nanesenih slojeva preslika. Vrlo oštećen, posebno po rubnim dijelovima slike, zbog neadekvatno izrađenog podokvira čiji su rubovi tijesno prianjali uz platneni nosilac pa su s lica bili vidljivi njegovi otisci. Tutkalno-kredna preparacija je popucala i velikim dijelom otpala do vidljivog platnenog nosioca oko cijelog oboda slike (velik je broj oštećenja ø 3-4 cm, a nebrojeno puno manjih) za koja se pretpostavlja da su ih uzrokovale žarulje montirane $\mathrm{u}$ obliku vjenčića ispred slike tijekom 30tih godina 20. stoljeća (Slika 15). Najjača oštećenja bila su vidljiva uz donji rub slike gdje je slikani sloj potpuno nedostajao u visini od $4 \mathrm{~cm}$. Uz donji rub bila su prisutna područja svijetlih, bijelih mrlja za koje se prije početka radova pretpostavljalo da

for the Conservation of Historic and Artistic Works, 1966., Vol. 7, No. 1, str. 8.-20.; Studies in conservation, 2002., Vol. 47, No. 2, str. 134.-138. 
su razvijene kolonije gljivica ili plijesni (Slika 16). Pored svih navedenih oštećenja kompletna površina sačuvanog, izvornog slikanog sloja bila je vidno prljava i prašnjava. Izvorne boje su potamnjele, što je bio rezultat godinama taložene prašine i prljavštine koja se stopila sa završnim slojem zaštitnog laka potamnjelog zbog procesa oksidacije.

d/ Ukrasni okvir bio je recentno izrađen od uskih i jednostavno profiliranih pozlaćenih letvica. Svojim skromnim dimenzijama profila nije bio prikladan za sliku te veličine. Osim toga bio je zatečen u lošem stanju, crvotočan, izvitoperen te ispucale i otpale pozlate potamnjele oksidacije i prljavštine. Vjerojatno je slika postavljena u nj nakon uklanjanja s oltara 70-tih godina 20. stoljeća.

\section{Konzervatorsko-restauratorski zahvat na slici ${ }^{22}$}

Slika je nakon preuzimanja u župnom dvoru RKT župe sv. Martina biskupa transportirana $u$ Restauratorski centar Ludbreg. ${ }^{23}$ Dezinsekcija je provedena $u$ komori za dezinsekciju anoksi metodom u trajanju od deset tjedana. ${ }^{24}$ Nakon dezinsekcije izrađena je fotografska dokumentacija zatečenog stanja slike.

Kako je analizama ustanovljeno da se radi o slici koja je sačuvala vrlo oštećeni izvorni slikani sloj, pristupilo se cjelovitom konzervatorsko-restauratorskom postupku.

Prije početka radova slika je morala biti odvojena od recentnog ukrasnog okvira i podokvira, pa je bilo potrebno pažljivo ukloniti korodirane industrijske čavliće kojima je platno bilo pričvršćeno za podokvir.

Slikani sloj bio je u vrlo trusnom stanju pa je prije početka uklanjanja površinske prljavštine s poleđine, na licu izveden facing ${ }^{25}$ (3\%-tno tutkalo i japanski papir). Uklanjanje nečistoće na naličju izvedeno je mehanički skalpelom, a potom dodatnim kemijskim postupkom (15\%-tni amonijak u vodi neutraliziran White spiritom) (Slika 17,18). Oštećenja od korodiranih čavala u vidu rupa na rubovima platnenog nosioca sanirana su umetanjem novog lanenog platna slične teksture i gustoće, učvršćenog lijepljenjem s pomoću poprečno položenih lanenih niti (Plextol B500 otopljen u destiliranoj vodi u omjeru 1:1).

22 Ugovor o radovima sklopljen je između Hrvatskog restauratorskog zavoda i RKT župe sv. Martina u Varaždinskim Toplicama pod brojem U-103/12. od 20. 6. 2012. Radovi su izvođeni 2012. i 2013. godine $\mathrm{u}$ radionici za štafelajno slikarstvo Restauratorskog centra $\mathrm{u}$ Ludbregu, a financiralo ih je Ministarstvo kulture Republike Hrvatske sredstvima za zaštitne radove na zaštićenim pokretnim spomenicima kulture koja su dodijeljena RKT župi sv. Martina u Varaždinskim Toplicama.

23 Revers o preuzimanju umjetnine br. RCL-38/12. od 15. srpnja 2012. godine.

24 Dezinsekcija je trajala deset tjedana u razdoblju od 18. srpnja do 20. rujna 2012. godine., a korištena je tzv. anoksi metoda uz primjenu inertnog plina dušika (N) koji nije štetan ni za ljude niti za okoliš.

25 Preventivno podljepljivanje cijele površine slike s lica. 
Nastavljeni su radovi s lica. Uz prethodno pažljivo uklanjanje ranije nanesenog japanskog papira pomoću destilirane vode pristupilo se ponovnom učvršćivanju za platneni nosilac minimalno odignutih dijelova slikanog sloja (5\%-tno kožno tutkalo). Uklanjanje potamnjelog laka i prljavštine s lica izvedeno je kemijski (aceton), a nakon toga i dočišćavanjem (5\%-tna amonijačna voda). Bijele mrlje u donjoj zoni slike tretirane su dezinficijensom. Neravnine platna izravnate su relaksacijom uz vlaženje s naličja (bugačice i destilirana voda) pod opterećenjem, a potom i parcijalnim izravnavanjem restauratorskom peglicom. Na svim oštećenim dijelovima slikanog sloja nanesen je Klucel kit (mješavina šampanjske i bolonjske krede u omjeru 1:1 u 5\%-noj otopini Klucela G u destiliranoj vodi), a potom tanki sloj kredno-tutkalne osnove koja je nivelirana s okolnim izvorno sačuvanim slikanim slojem. Nova kredna preparacija izolirana je (5\%-tni šelakom $\mathrm{u}$ etanolu), zatim je nanesen prvi sloj boje tzv. podslik (akvarelne boje Winsor \& Newton) kojim su izvedena nužna toniranja novih dijelova preparacije.

Zbog bojazni da bi pri napinjanju slike na novi podokvir moglo doći do djelomičnog pucanja već ionako oslabljenog izvornog platnenog nosioca te radi dodatnog ojačanja slike, pristupilo se dubliranju, tj. reantolaži ${ }^{26}$ na novu platnenu osnovu (laneno platno, Gustav Berger`s O.F. 371 /Beva gel/ 371/40\% solution razrijeđena medicinskim benzinom do potrebnog viskoziteta) na toplinskom vakuumskom stolu uz potlak i temperaturu od $70{ }^{\circ} \mathrm{C}$. ${ }^{27}$ Izrađen je novi podokvir od jelovog drveta (letve dimenzija 6 × 2,8 cm) spojen na pera u tzv. francuski vez, kojemu su dodane istake debljine $5 \mathrm{~mm}$ duž vanjskih rubova kako bi se platno fizički odvojilo od drvene površine okvira. Podokviru je dodan i križ u gornjoj trećini slike na peti luka te je uvučen $1 \mathrm{~cm}$ u odnosu na debljinu podokvira kako bi se povećao razmak između platna i letvi križa s podokvira. Na tako izrađen podokvir slika je ponovno napeta metalnim klamericama koje su izolirane od platnenog nosioca beskiselinskom papirnatom ljepenkom. (Slika 19.) Završni retuš izveden je pigmentima u prahu (Krämer) u Gummi arabicu i lazurnim restauratorskim bojama "Restauro" s malo terpentina i damara (omjer 1:8). Završno lakiranje radi zaštite slikanog sloja izvedeno je 2\%-tnim Damar lakom u terpentinskom ulju. (Slika 2023, 24-29) Nakon završenih radova 2013. godine slika je ponovno pohranjena u prostorijama župnog dvora u Varaždinskim Toplicama. ${ }^{28}$

26 Cjelovito podlaganje slike s naličja novim platnenim nosiocem u svrhu ojačanja. 
Venija Bobnjarić-Vučković: Nove spoznaje o oltarnoj slici sv. Martina iz župne crkve u Varaždinskim Toplicama Radovi Zavoda za znanstveni rad HAZU Varaždin; br. 29, 2018., str. 53-84

\section{REZULTATI PROVEDENIH ISTRAŽIVANJA I RADOVA}

Slika sv. Martina, koja se nalazila na glavnom oltaru župne crkve sv. Martina u Varaždinskim Toplicama, prema dostupnoj se dokumentaciji iz Konzervatorskog odjela Ministarstva kulture smatrala radom nepoznatog majstora iz 18. stoljeća.

Analiza stilsko-formalnih karakteristika slike govori u prilog tvrdnji o njezinu kasnijem nastanku, sredinom 19. stoljeća, a to je tijekom konzervatorsko-restauratorskih radova potvrđeno otkrivanjem izvorno sačuvane signature autora s godinom nastanka koja se nalazila ispod ukrasnog okvira u donjem desnom uglu slike. Identifikacijom signature autora, a potom raspoloživim izvorima i literaturom potvrđeno je da je sliku izradio austrijski slikar i restaurator Johann Beyera 1852. godine. On je u periodu od 1846. do 1860. godine djelovao i na području sjeverozapadne Hrvatske i izradio niz oltarnih pala za crkve. Među inim palama navedena je i slika koju je naslikao za crkvu u selu Svibovec kod V. Toplica. Godina njenog nastanka nije navedena u Hrvatskom biografskom leksikonu, no, Beyerov boravak u Svibovcu morao se zbiti u periodu njegovog djelovanja $u$ Hrvatskoj, tako da je s velikom sigurnošću moguće tvrditi da je u tom razdoblju od njega bila naručena i naslikana slika za oltar u Varaždinskim Toplicama.

Slika je najvjerojatnije bila naručena za stariji barokni oltar koji se u godinama Beyerovog djelovanja u Hrvatskoj još uvijek nalazio u svetištu župne crkve sv. Martina. Prema dostupnim podacima o dva sačuvana kasnobarokna relikvijara s glavnog oltara i na fotografiji evidentiranom svetohraništu za pretpostaviti je da je i oltar, kojemu su ti elementi pripadali, bio izrađen $u$ istoj bijelo-zlatnoj kasnobarokno-klasicističkoj maniri.

Trideset godina nakon nastanka slike sv. Martina došlo je do uklanjanja starog, drvenog, baroknog oltara iz svetišta crkve, što se zbilo između 1882. i 1884. godine, i postavljanja novog, mramornog oltara sv. Katarine iz zagrebačke katedrale autora Francesca Robbe. Tako je crkva u Varaždinskim Toplicama krajem 19. st. dobila novi oltar u koji je smještena slika sv. Martina autora Johanna Beyera. Prilikom restauratorskih radova uočene su na rubovima slike tragovi naknadnih korekcija njenih dimenzija čime se potvrđuje pretpostavka da je slika mijenjala svoje izvorno mjesto i prilagođavala se dimenzijama otvora novog, kamenog oltara. Godine 1930. bile su još nepovoljnije za sudbinu slike i njeno stanje jer se prilikom uvođenja struje u crkvu, o čemu se navodi podatak u spomenici župe, oko slike i skulpture u niši atike dodaju ukrasni vjenčići od žarulja. Takvo stanje dokumentira i u radu objavljena fotografija iz 1930-tih godina. Djelovanje topline žarulja u narednom razdoblju prouzročilo je velika oštećenja na slikanoj površini i nosiocu koja su bila evidentirana prilikom restauracije 2012. godine. 
Venija Bobnjarić-Vučković: Nove spoznaje o oltarnoj slici sv. Martina iz župne crkve u Varaždinskim Toplicama Radovi Zavoda za znanstveni rad HAZU Varaždin; br. 29, 2018., str. 53-84

Nadalje, 1950. godine slika je preseljena u zonu atike oltara, gdje ju je ponovno trebalo prilagoditi novoj poziciji jer se kao pala glavnom oltaru vraća izvorni, ranije uklonjeni kameni reljef s motivom muke sv. Katarine. Slika sv. Martina na atici ostaje narednih trideset godina kada se $\mathrm{u}$ potpunosti uklanja s oltara, vjerojatno zbog nastalih oštećenja, i stavlja van liturgijske funkcije te pohranjuje u župnom dvoru.

\section{ZAKLJUČAK}

Na temelju rezultata provedenih arhivskih, povijesno-umjetničkih i konzervatorsko-restauratorskih istraživanja i radova može se zaključiti da je slika rad poznatog autora nastala sredinom 19. st. te da je sačuvana u izvornom stanju. No, kako je tijekom vremena mijenjala položaj na oltarima i bila izložena različitim uvjetima koji su neposredno utjecali na njeno stanje, doživjela je manje modifikacije u dimenzijama, ali je zato zadobila vrlo velika oštećenja zbog čega je u konačnici stavljena van funkcije i uklonjena iz crkve.

Za sagledavanje cjelovitijeg konteksta u kojem je slika nastala i što se s njom zbivalo tijekom smještaja u crkvi na oltaru bilo bi potrebno provesti dodatna arhivska istraživanja usmjerena na period barokne obnove crkve u 2. pol. 18. stoljeća kada nastaje jedan dio inventara koji je dijelom sačuvan do danas, a dijelom izgubljen zbog promjena do kojih je došlo krajem 19. stoljeća.

Buduća istraživanja bi trebalo usmjeriti ka cjelovitom opusu Johanna Beyera iz razdoblja njegovog djelovanja na području sjeverozapadne Hrvatske, a posebice u 50-tim godinama 19. stoljeća kada je najvjerojatnije boravio i radio sliku u selu Svibovec što bi moglo donijeti još čvršće dokaze, a time i potvrde njegovog boravka i rada na slici za oltar u župnoj crkvi u Varaždinskim Toplicama.

\section{LITERATURA I IZVORI}

1. Agramer Zeitung (Zagreb), 30. studeni 1847., br. 96, str. 430.

2. Arhiv župe sv. Martina Varaždinske Toplice (dalje: AŽVT), Napisnik znamenitih događanja u župi topličkoj od 1863. godine.

3. Arhiva Restauratorskog centra Hrvatskog restauratorskog zavoda u Ludbregu (dalje: ARCL), Dokumentacija konzervatorsko-restauratorskih radova na slici sv. Martina iz župne crkve Sv. Martina u Varaždinskim Toplicama, Dos. br. 56.2., Ludbreg 2012.-2013.

4. Arhiva Restauratorskog centra Hrvatskog restauratorskog zavoda u Ludbregu (dalje: ARCL), Dokumentacija konzervatorsko-restauratorskih radova na moćnicima iz župne crkve Sv. Martina u Varaždinskim Toplicama, Dos.br. 56.3, Ludbreg, 2012.-2014. 
5. „Beyer J.“, Hrvatski biografski leksikon, sv. I, gl. urednik dr. Nikica Kolumbić, Zagreb, 1983., 734-735

6. Crkvena umjetnost $i$ baština novomarofskog kraja. Katalog izložbe. Varaždin, 1992.

7. Josip ČABRIJAN, „Varaždinske Toplice u srednjem vijeku“, Vijesti muzealaca $i$ konzervatora Hrvatske 15, Zagreb, 1966., 16.-23.

8. „Beyer, 2. Johann“, Enciklopedija likovnih umjetnosti, svezak 1, gl. redaktori S. Batušić/A. Mohorovičić/M. Šeper, Zagreb, 1966., str. 360.

9. „Varaždinske toplice“, Enciklopedija likovnih umjetnosti, svezak 4, gl. redaktori S. Batušić/A. Mohorovičić/M. Šeper, Zagreb, 1966., str. 491.-492.

10. Božena FILIPAN, „,Barokna baština Varaždinskih toplica s osvrtom na zaštitu i revitalizaciju“, Zavod za znanstveni rad HAZU-a Varaždin, Radovi Zavoda za znanstveni rad HAZU Varaždin 8-9., Zagreb - Varaždin, 1996., 41.-73.

11. Vera HORVAT-PINTARIĆ, Francesco Robba, Zagreb, 1961., 18.-21.

12. Stana KOVAČEVIĆ, Ručno tkanje, Zagreb, 2003., 84.-85.

13. "Martin, biskup, sveti“, Leksikon ikonografije, liturgike i simbolike zapadnog kršćanstva, ured. Anđelko Badurina, Kršćanska sadašnjost, Zagreb, 1990., str. 397.-398.

14. Ivy LENTIĆ KUGLI, „Arhitektura u povijesnoj urbanoj cjelini Varaždinskih Toplica“, Arhitektura, Zagreb, 1975., 154, 57.-59.

15. Đuro SZABO, Kroz Hrvatsko zagorje, Zagreb, 1939., 162.-164.

16. Fototeka Uprave za zaštitu kulturne baštine Ministarstva kulture RH (dalje: FUZKB)

17. Josef WASTLER, Steirisches Kuenstler-Lexicon, Verlag „Leykam“, Graz, 1883., 5-6

18. R. D. HARLEY, Artists` Pigments c. 1600-1835. Butterworth Scientific, London, 1982., 172.

19. M. H. B. HERING, Weisse Farbmittel, Dr. M. H. B. Hering furth, Nurnberg, 2000, 69.-85.

20. R. FELLER, „First description of dammar picture varnish translated“, Bulletin of the American Group. International Institute for the Conservation of Historic and Artistic Works, 1966., br. 7/1, 8.- 20. 


\section{SAŽETAK \\ NOVE SPOZNAJE O OLTARNOJ SLICI SV. MARTINA IZ ŽUPNE CRKVE U VARAŽDINSKIM TOPLICAMA}

Slika sv. Martina datirana je u 18. stoljeće te se pretpostavlja da je izvorno pripadala starijem drvenom i polikromiranom oltaru iz razdoblja obnove crkve i inventara šezdesetih godina 18. stoljeća. Potkraj 19. stoljeća stari oltar zamijenjen je oltarom sv. Katarine iz zagrebačke katedrale, autora F. Robbe, i od tada slika u nekoliko navrata mijenja svoj položaj na oltaru. U prvo se vrijeme slika nalazila na novom oltaru kao glavna oltarna slika, a tridesetih je godina 20. stoljeća premještena na atiku oltara. Konačno je sedamdesetih godina 20. st. potpuno uklonjena s oltara i pohranjena u župnom dvoru, gdje se trajno čuvala.

Na slici sv. Martina su tijekom 2012. i 2013. godine provedeni cjeloviti konzervatorsko-restauratorski radovi. Tijekom tih radova, a nakon faze uklanjanja potamnjelog laka, otkrivana signatura autora s godinom nastanka slike. Tim otkrićem korigirana je datacija slike na 1852. godinu te je utvrđeno da je autor Johann Beyer iz Austrije koji je od 1840-ih do 1860-ih godina izradio niz oltarnih slika u Hrvatskoj pa tako i sliku za Svibovec kod Varaždinskih Toplica. Temeljem prikupljenih podataka može se pretpostaviti da je tom prilikom nastala i nova oltarna slika za barokni oltar iz crkve sv. Martina u Varaždinskim Toplicama. Slika je u cijelosti restaurirana podlaganjem novom tkaninom za ojačanje platnenog nosioca, izrađen je novi podokvir i ukrasni okvir te je nakon završenih radova vraćena u župni dvor u Varaždinskim Toplicama. Radovi su se provodili u Restauratorskom centru Hrvatskog restauratorskog zavoda u Ludbregu, a financirani su sredstvima Ministarstva kulture Republike Hrvatske.

Ključne riječi: župna crkva sv. Martina; oltar sv. Martina; oltarna slika sv. Martina; arhivska istraživanja; Johann Beyer; konzervatorsko-restauratorski radovi. 


\section{SUMMARY}

\section{NEW DISCOVERIES OF THE ALTARPIECE OF ST. MARTIN FROM THE PARISH CHURCH IN VARAŽDINSKE TOPLICE}

The painting of St. Martin is dated to the $18^{\text {th }}$ century and presumed to have originally belonged to an earlier wooden and polychromed altar from the time the church and its furnishing were renovated in the $1760 \mathrm{~s}$. In the late $19^{\text {th }}$ century, the old altar was replaced by Francesco Robba's altar of St. Catherine from Zagreb Cathedral, and since then the painting had on several occasions changed its location on the altar. It was first situated on the new altar as the main altarpiece, to be moved in the 1930s to the altar attic. Finally, in the 1970s it was completely removed from the altar and stored in the parish rectory, where it has remained kept to this day.

Ludbreg Conservation Centre of the Croatian Conservation Institute carried out comprehensive conservation work on the painting of St. Martin from 2012 to 2013. In the course of these efforts, once the darkened varnish was removed, the author's signature was uncovered with the year the painting had originated. This discovery corrected the painting's dating to 1852, while the author was revealed to be Johann Beyer from Austria, who painted a series of altarpieces in Croatia from the 1840s to 1860 s, including a painting for Svibovec near Varaždinske Toplice. Based on the records collected, it can be assumed that it was on this occasion that a new altarpiece was commissioned for the Baroque altar of St. Martin in Varaždinske Toplice. The painting was fully restored by relining the canvas with a new fabric to strengthen the support, a new stretcher and decorative frame were made, and upon the completion of conservation, it was returned to the parish rectory in Varaždinske Toplice. The work was financed by the Croatian Ministry of Culture.

Key Words: parish church of St. Martin; altar of St. Martin; altarpiece of St. Martin; archival research; Johann Beyer; conservation work. 


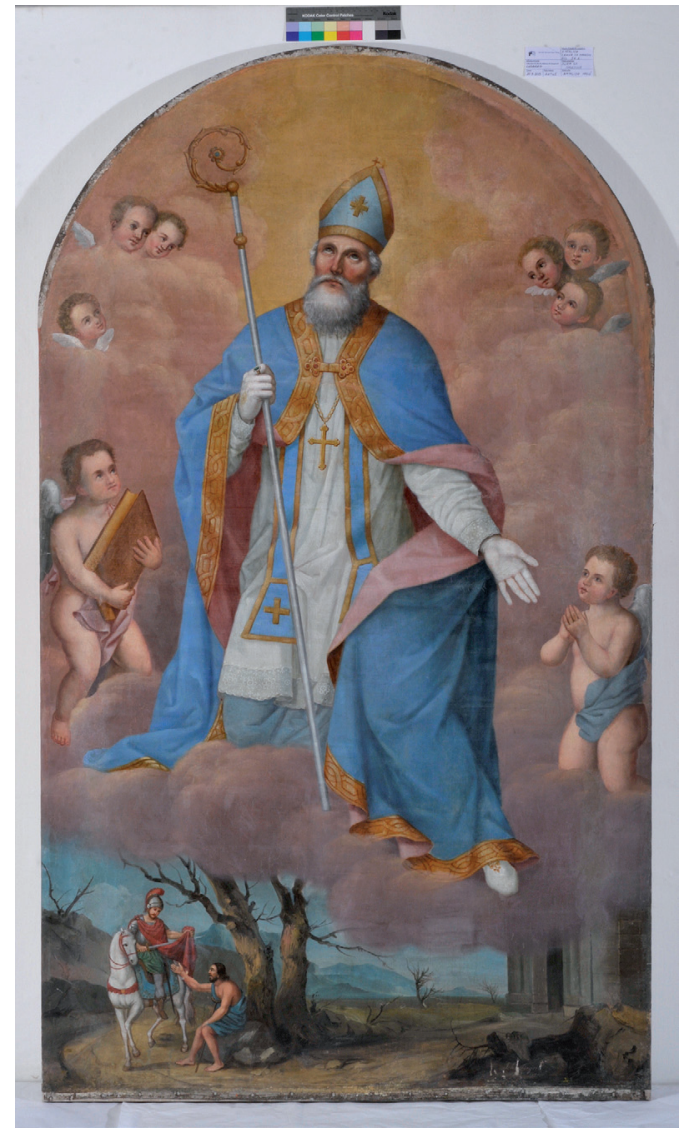

Slika 1. Slika sv. Martina nakon završenih radova (Arhiva HRZ RC Ludbreg, 2013.) 


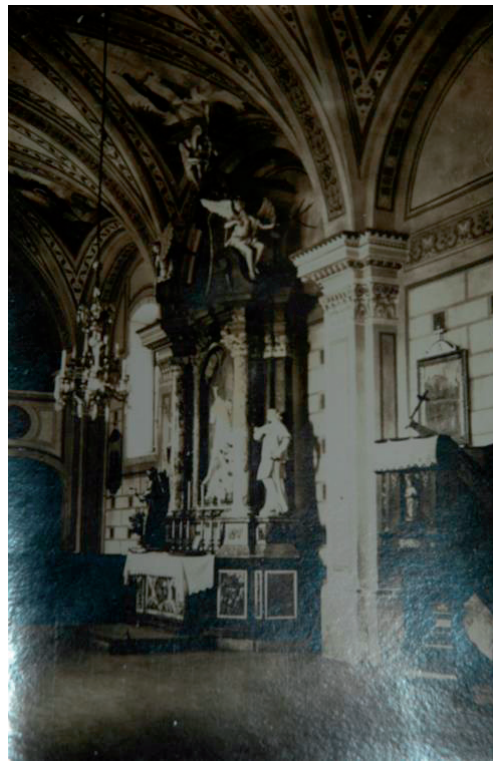

Slika 2. Sjeverni zid lađe, desno detalj reljefa sv. Katarine postavljen iz propovjedaonice (snimio Gj. Szabo, 1915.)

(presnimljeno iz arhive rkt župe $\mathrm{V}$. Toplice)

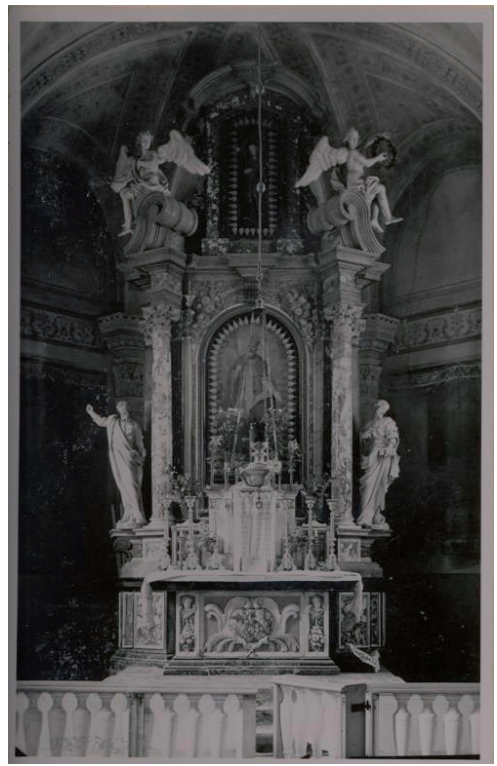

Slika 3. Glavni oltar snimljen 1930tih (Fototeka MK-UZZKB-F, inv. br. 31.404) 


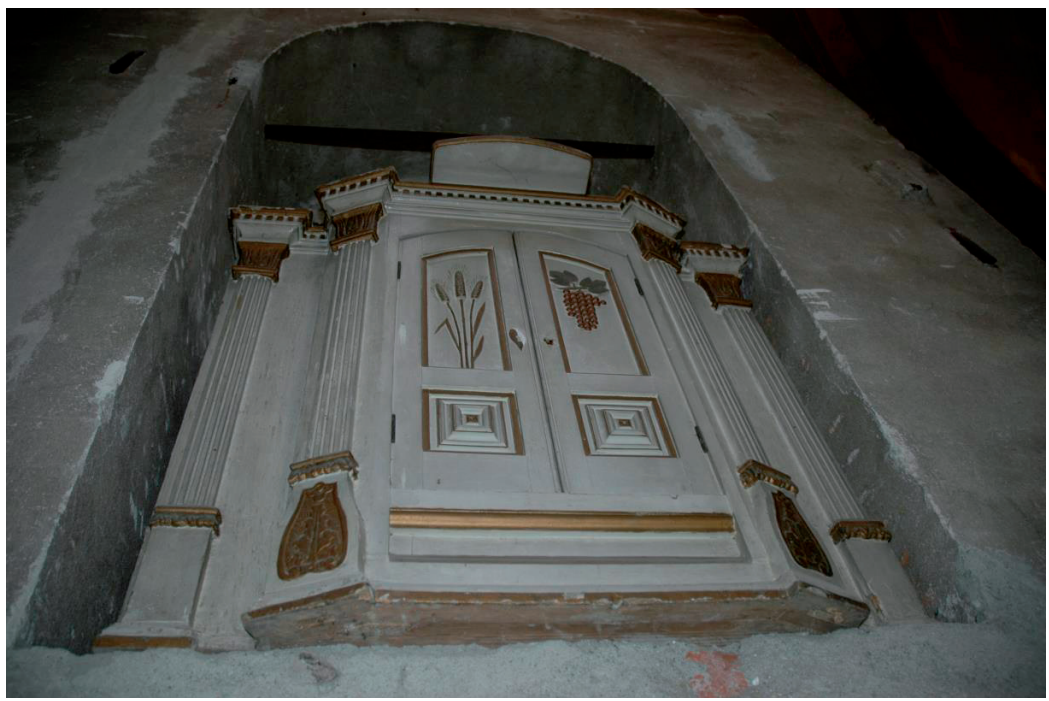

Slika 4. Stari drveni bijelo-zlatno polikromirani tabernakul, in situ u niši iza oltara (Arhiva HRZ RC Ludbeg, 2013.)

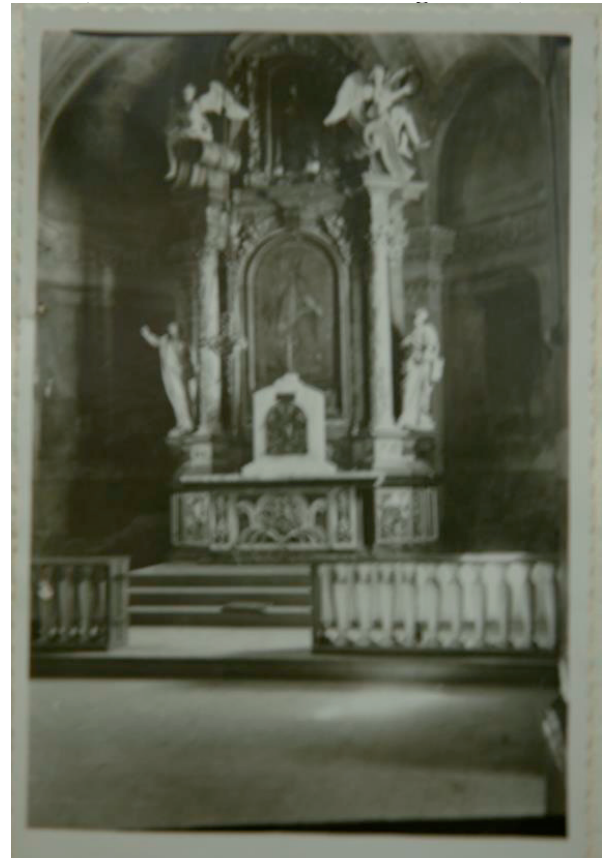

Slika 5. Glavni oltar 1954. godine (presnimljeno iz arhive RKT župe sv. Martina) 


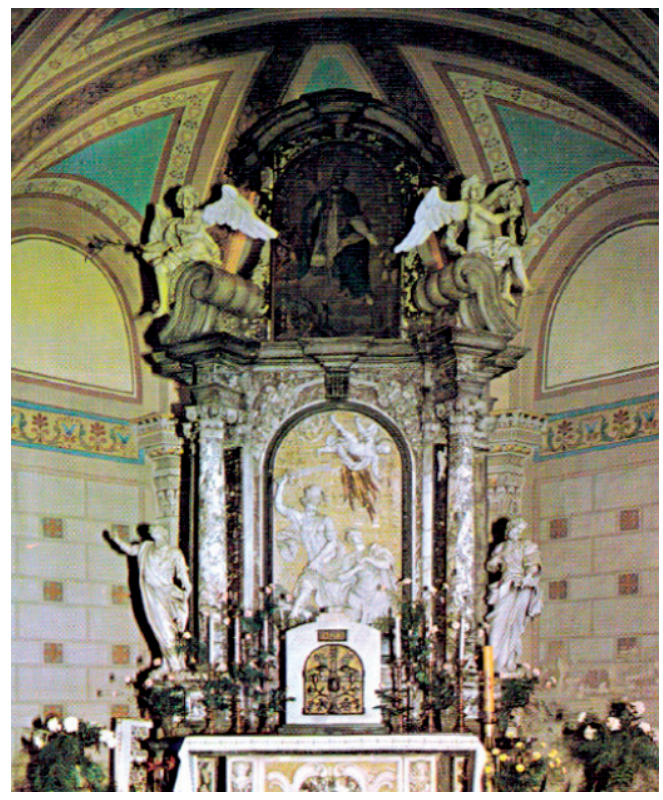

Slika 6. Glavni oltar 1979. godine na razglednici V. Toplica (presnimljeno iz arhive RKT župe sv. Martina)

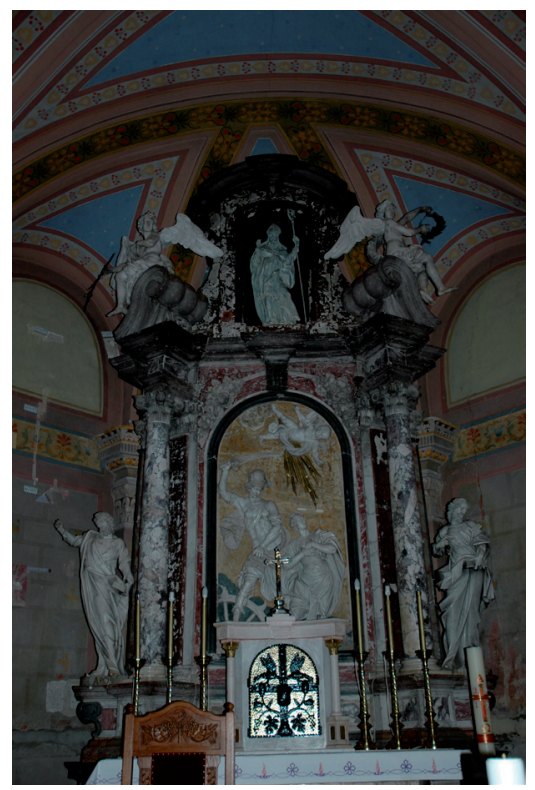

Slika 7. Glavni oltar 2013. godine (Arhiva HRZ RC Ludbreg, 2013.) 


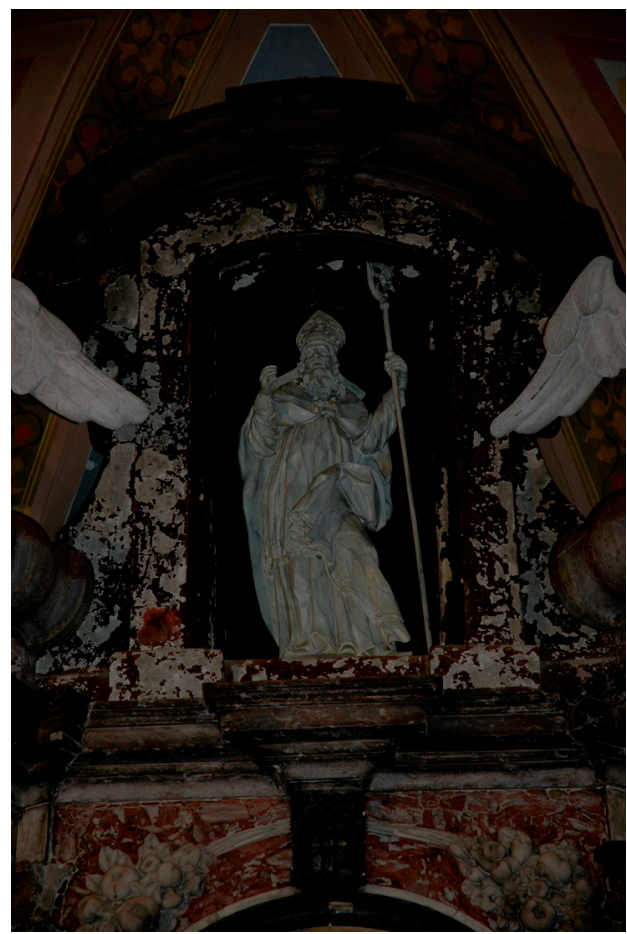

Slika 8. Atika glavnog oltara sa skulpturom biskupa u središnjoj niši (Arhiva HRZ RC Ludbreg)

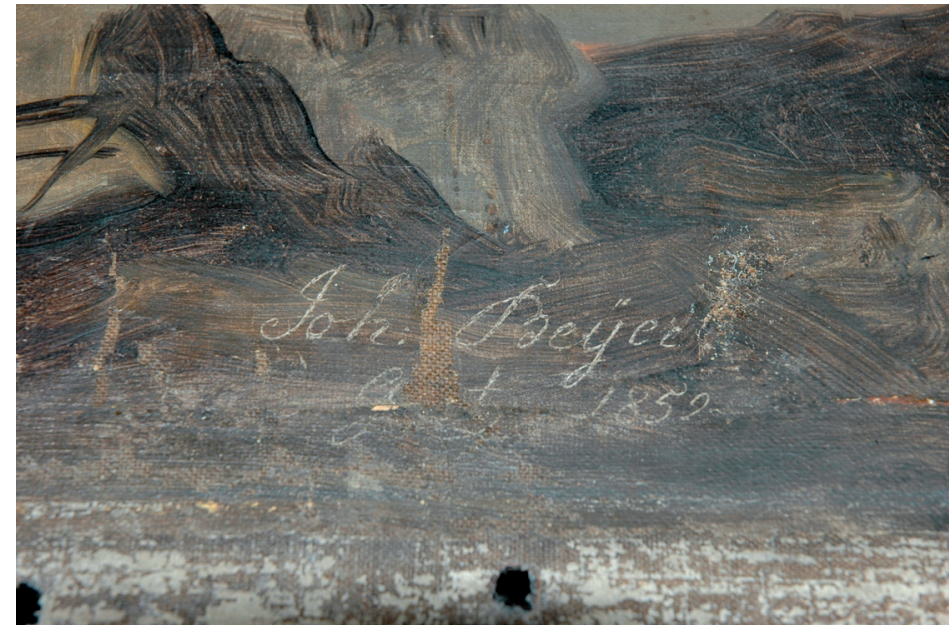

Slika 9. Detalj donjeg desnog ugla slike s otkrivenim potpisom autora Johanna Beyera iz 1852. (Arhiva HRZ RC Ludbreg, 2012.) 


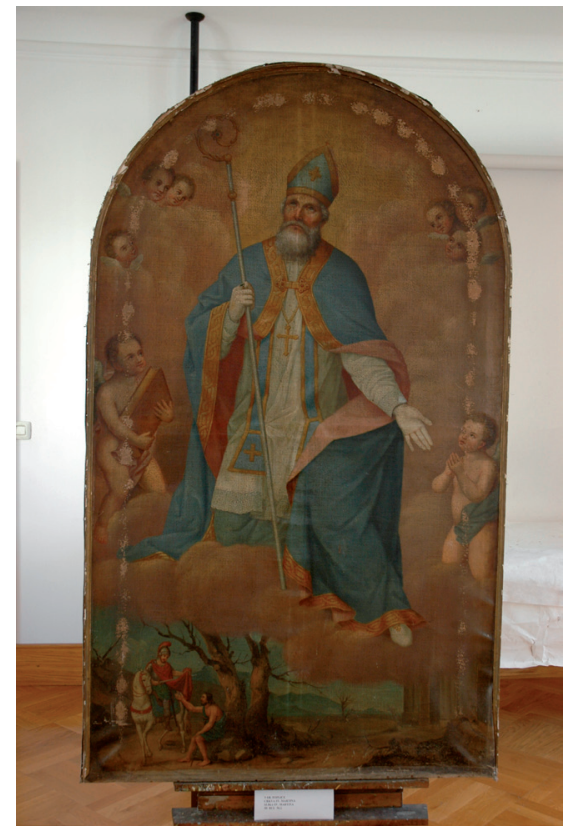

Slika 10. Slika sv. Martina iz crkve sv. Martina u V. Toplicama, zatečeno stanje prije radova (Arhiva HRZ RC Ludbreg, 2012.)

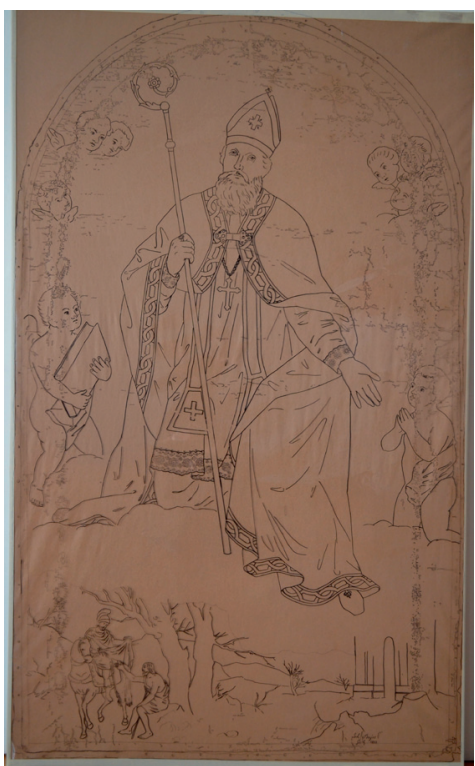

Slika 11. Skica oštećenja u omjeru 1-1 


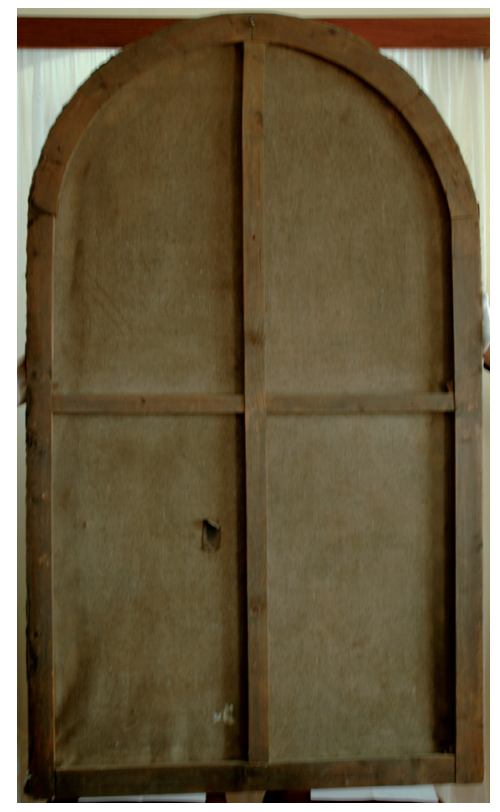

Slika 12. Pozadina sa starim podokvirom prije radova

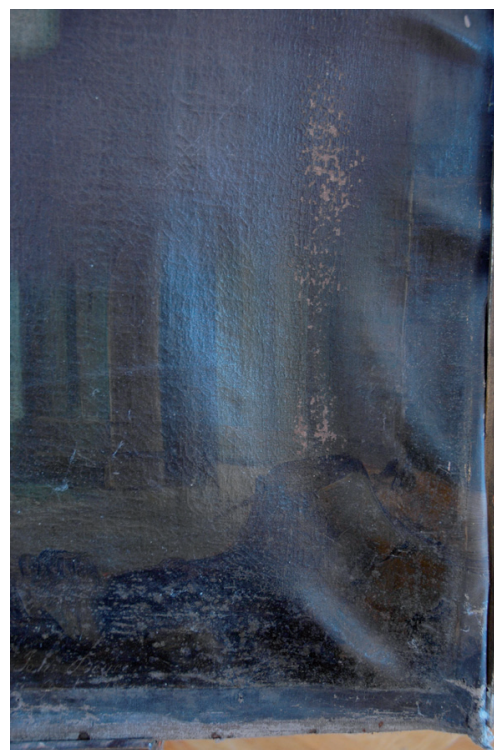

Slika 13. Detalj slike, dolje desno, prije radova s vidljivim oštećenjem platnenog nosioca (izvitopereno) (Arhiva HRZ RC Ludbreg, 2012.) 


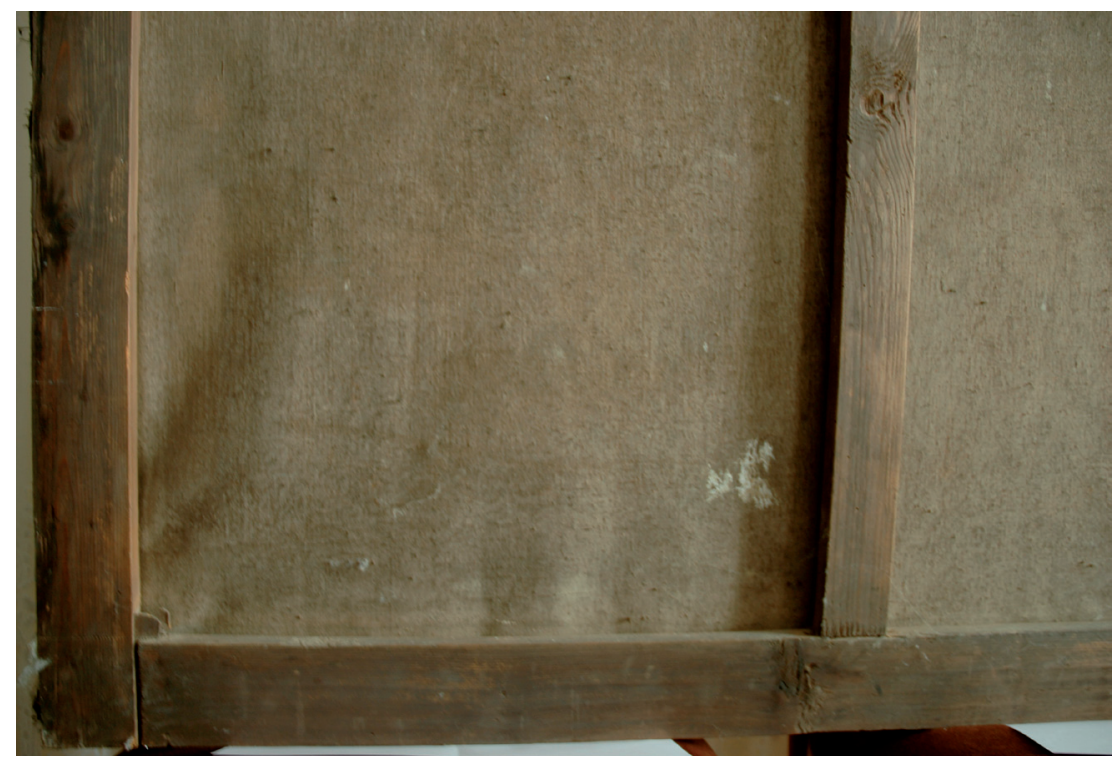

Slika 14. Detalj poleđine s podokvirom prije radova

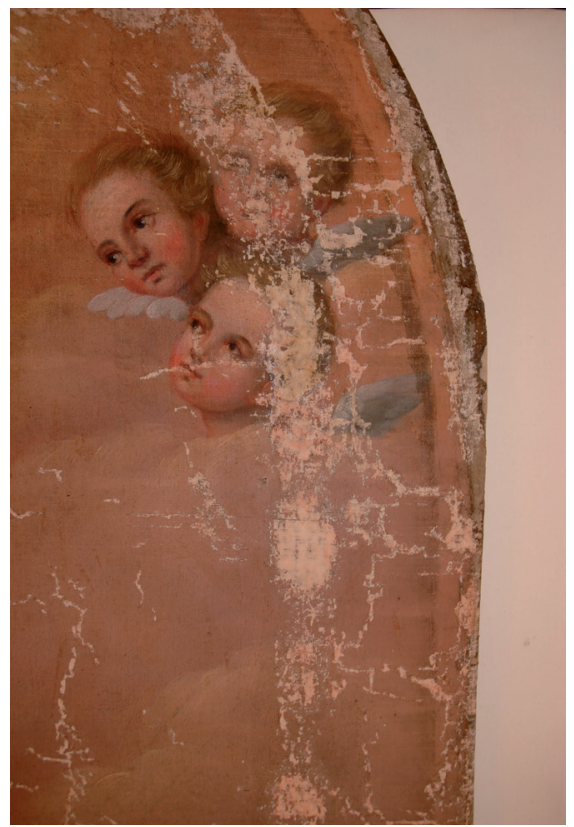

Slika 15. Detalj slike, gore desno, s vidljivim oštećenjem slikanog sloja i platnenog nosioca. (Arhiva HRZ RC Ludbreg, 2012.) 


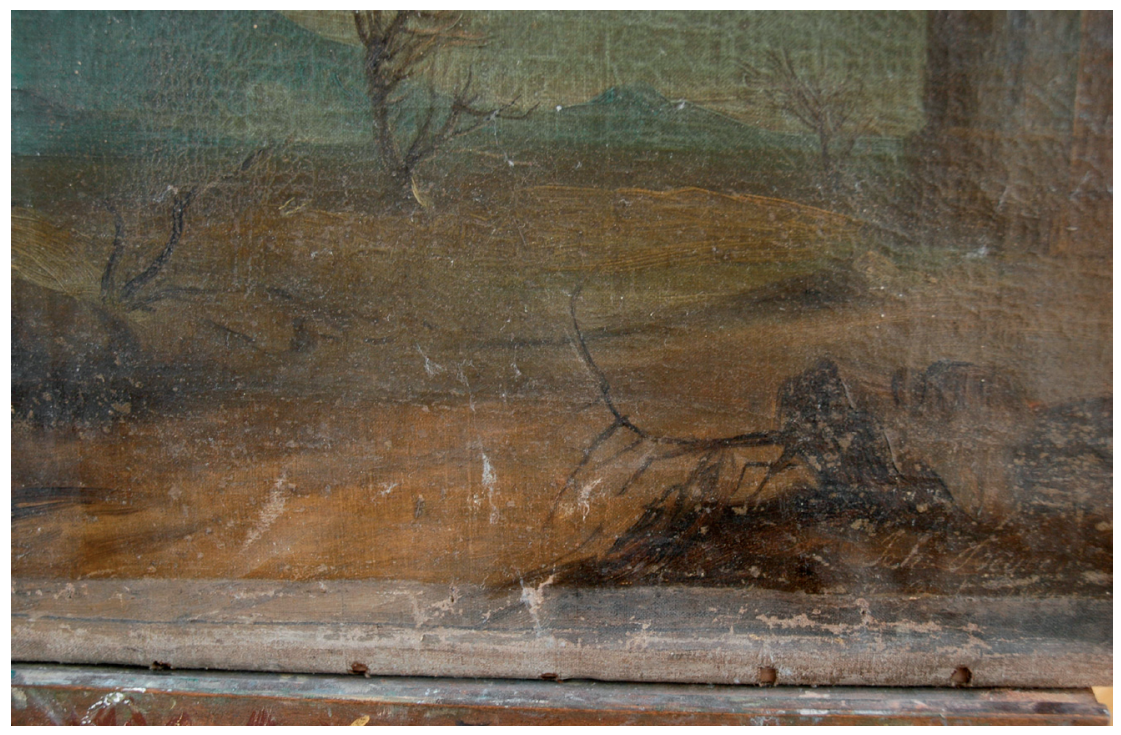

Slika 16. Detalje lica prije radova

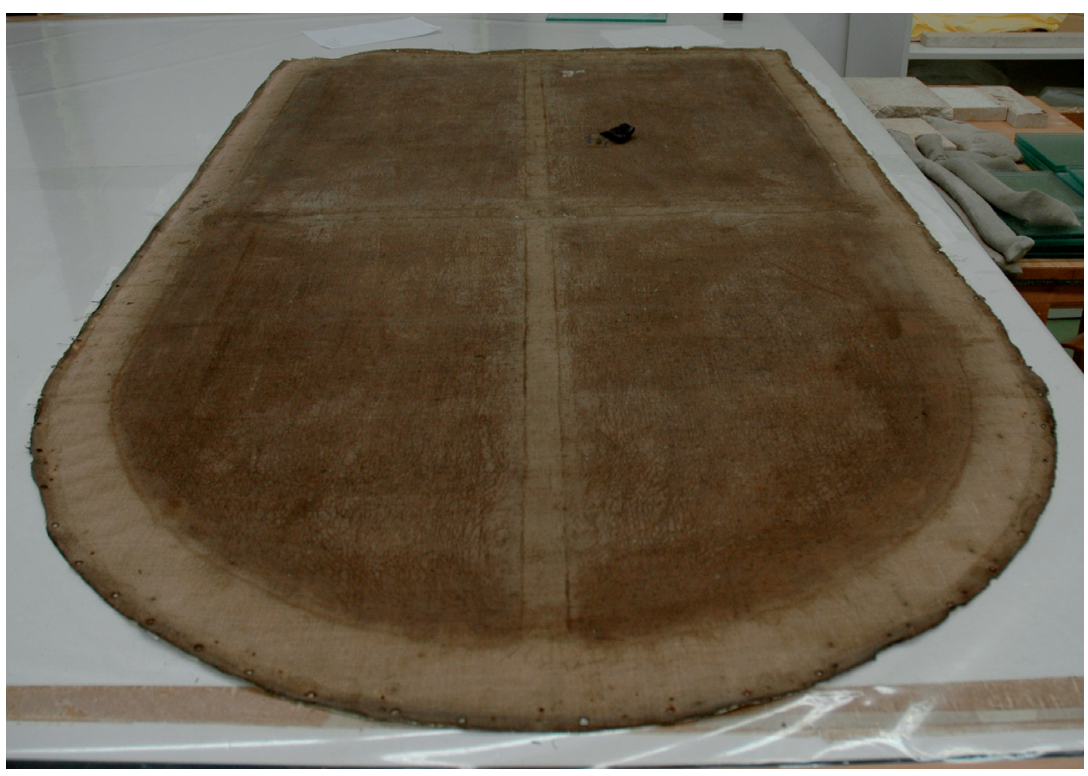

Slika 17. Poleđina slike nakon uklanjanja podokvira 


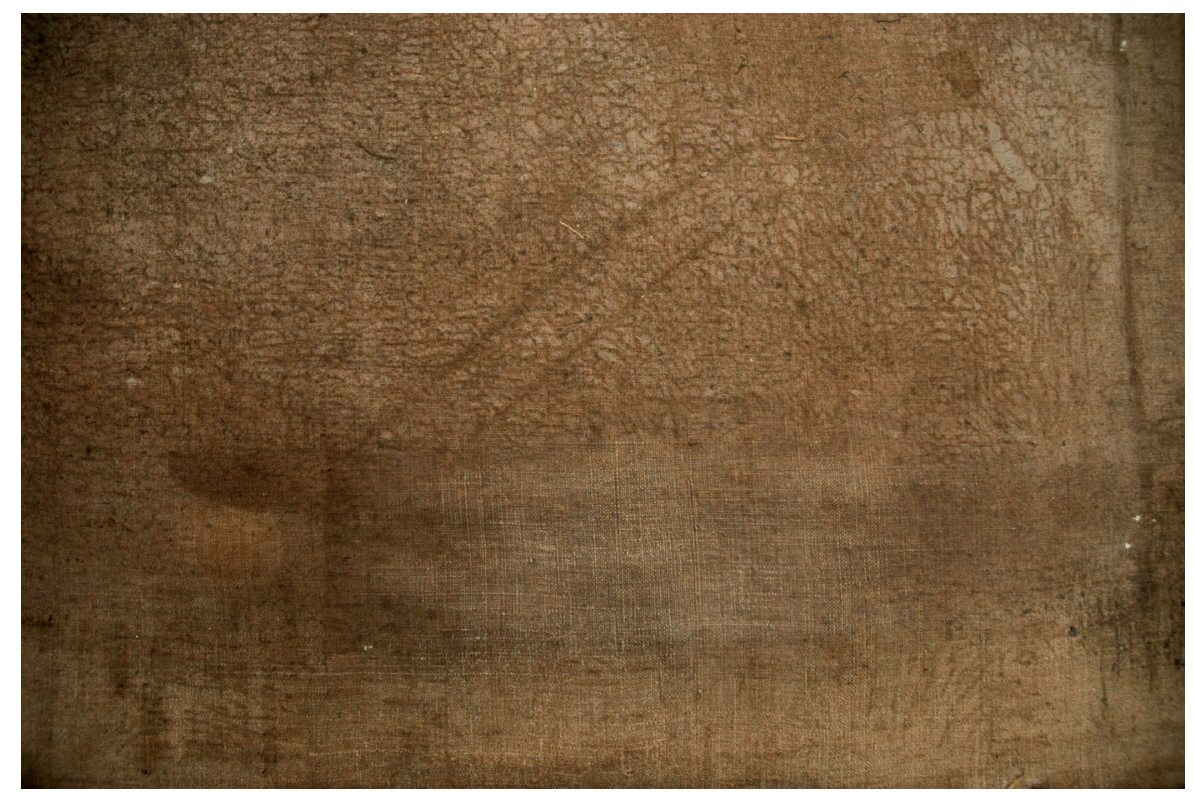

Slika 18. Detalj platnenog nosioca s poleđine u tijeku čišćenja

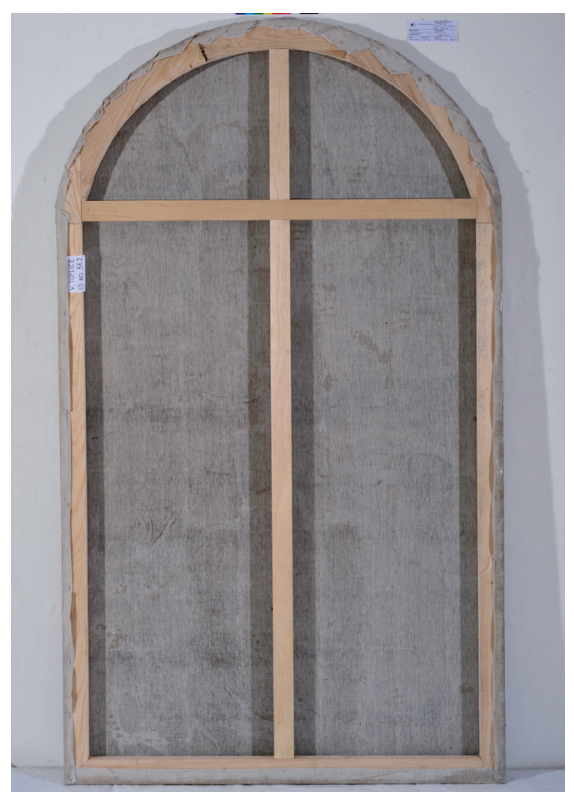

Slika 19. Pozadina slike nakon radova, s novim podokvirom i platnenim nosiocem. (Arhiva HRZ RC Ludbreg, 2013.) 


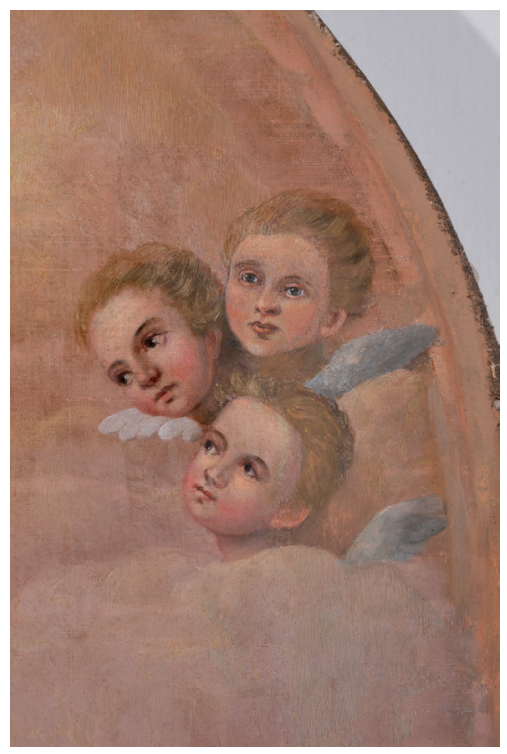

Slika 20. Detalj slike, gore desno, nakon retuša. (Arhiva HRZ RC Ludbreg, 2013.)

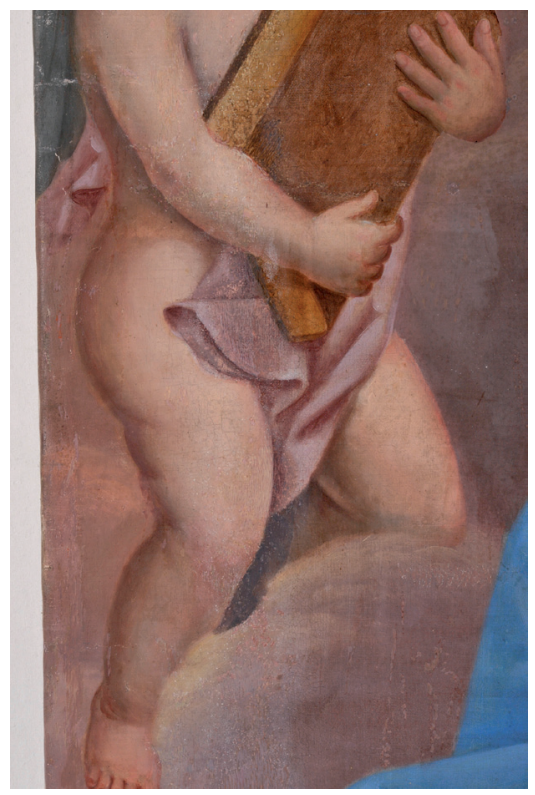

Slika 21. Detalj slike, sredina lijevo, nakon retuša (Arhiva HRZ RC Ludbreg, 2013.) 


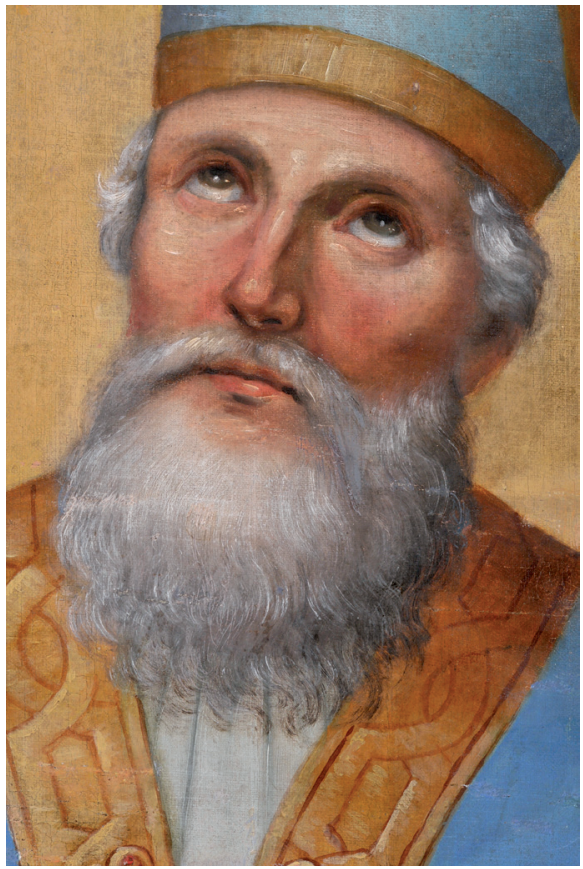

Slika 22. Detalj sv. Martina nakon retuša

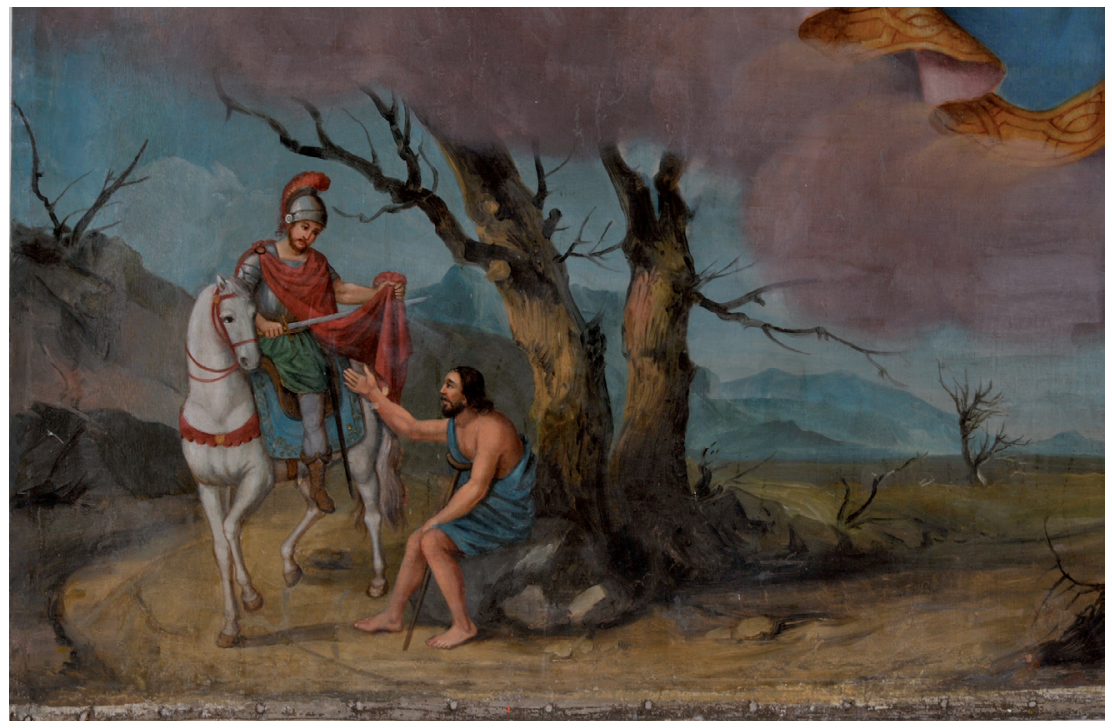

Slika 23. Detalj scene u donjem dijelu slike nakon retuša 


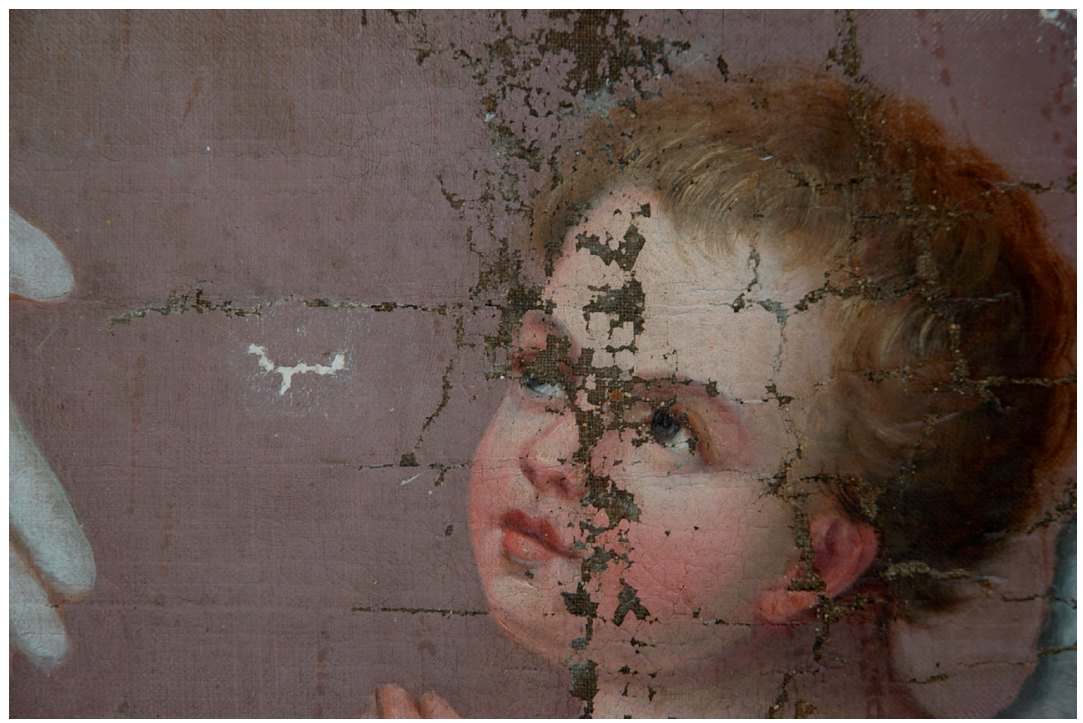

Slika 24. Detalj anđela prije krediranja oštećenih dijelova slikanog sloja (4)

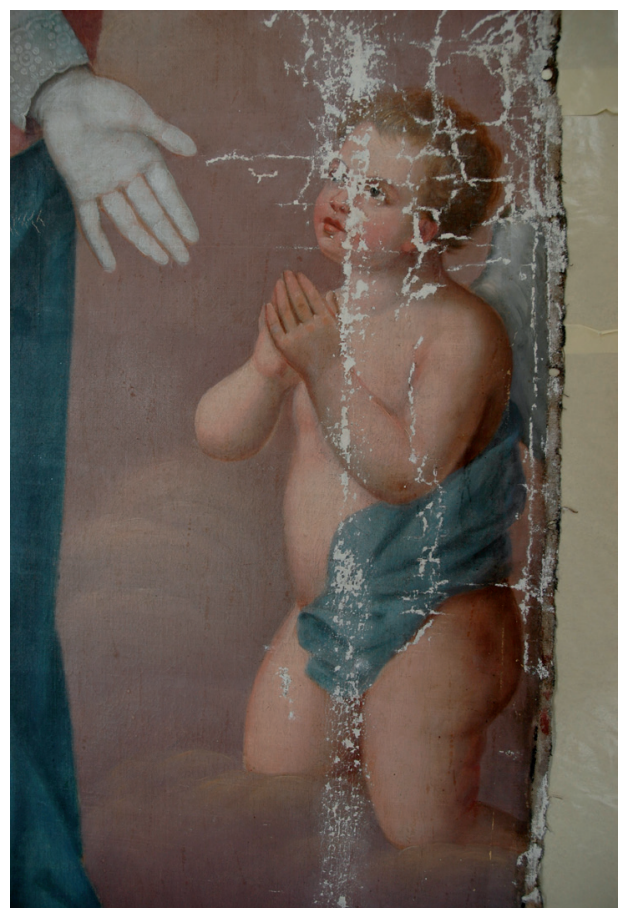

Slika 25. Detalj anđela nakon krediranje oštećenih dijelova slikanog sloja (56) 


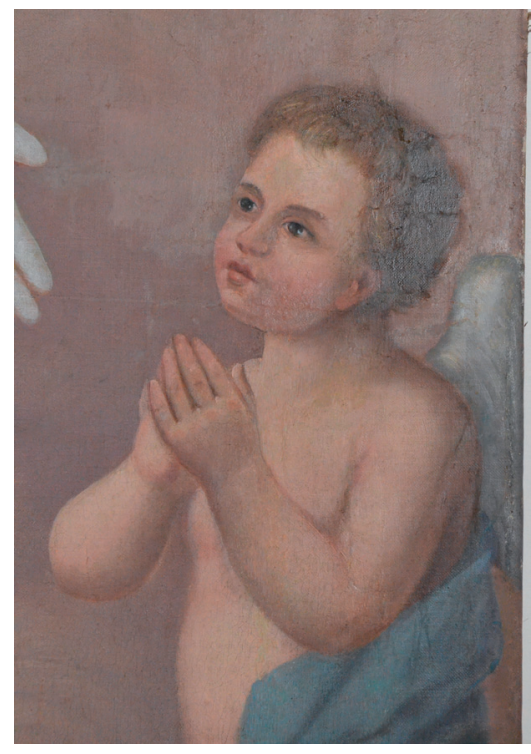

Slika 26. Detalj anđela nakon retuša

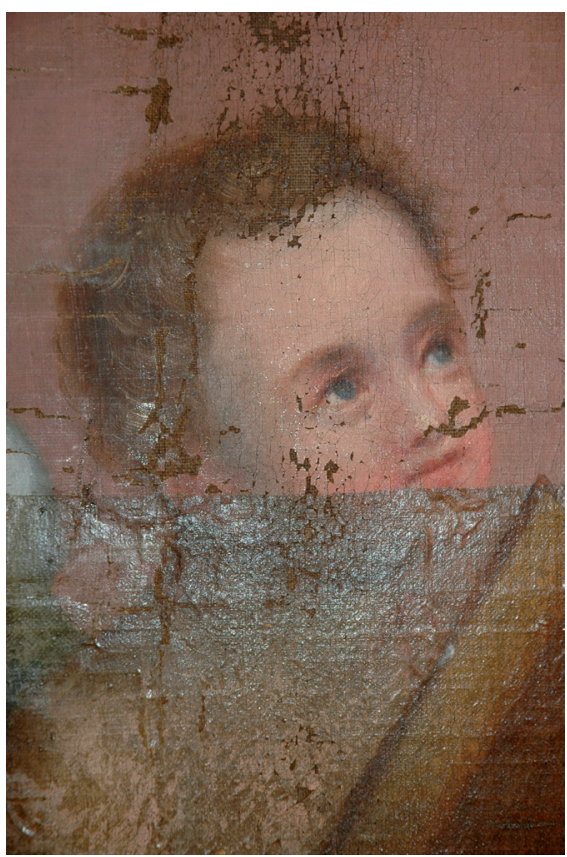

Slika 27. Detalj anđela s knjigom u tijeku uklanjanja nečistoće i zaštitnog laka s lica 


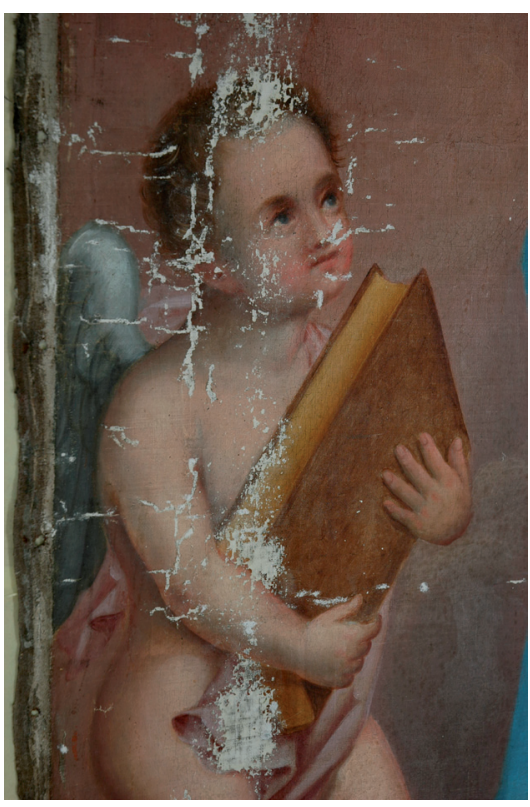

Slika 28. Detalj anđela s knjigom u fazi krediranja oštećenih dijelova slikanog sloja (16)

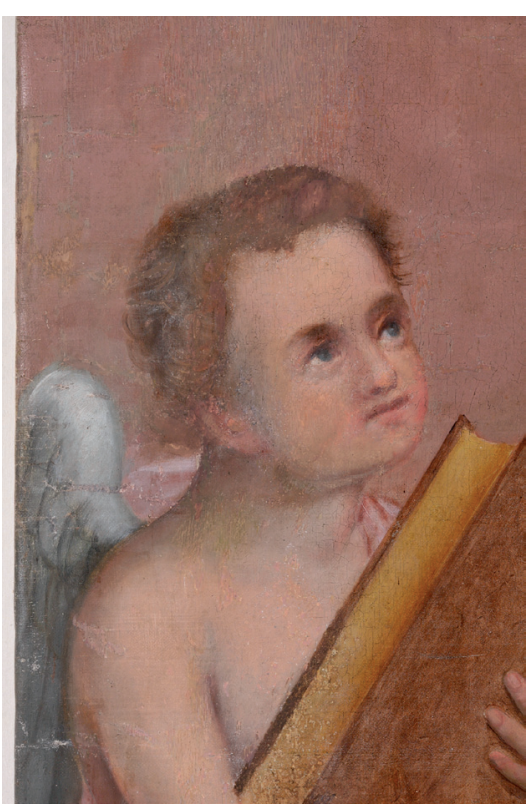

Slika 29. Detalj anđela s knjigom nakon retuša 